\title{
5. LOWER CRETACEOUS SMARL TURBIDITES OF THE ARGO ABYSSAL PLAIN, INDIAN OCEAN ${ }^{1}$
}

\author{
Julie A. Dumoulin ${ }^{2,3}$
}

\begin{abstract}
Sediments recovered during Ocean Drilling Program (ODP) Leg 123 from the Argo Abyssal Plain (AAP) consist largely of turbidites derived from the adjacent Australian continental margin. The oldest abundant turbidites are Valanginian-Aptian in age and have a mixed (smarl) composition; they contain subequal amounts of calcareous and siliceous biogenic components, as well as clay and lesser quartz. Most are thin-bedded, fine sand- to mud-sized, and best described by Stow and Piper's model (1984) for fine-grained biogenic turbidites. Thicker (to $3 \mathrm{~m}$ ), coarser-grained (medium-to-coarse sand-sized) turbidites fit Bouma's model (1962) for sandy turbidites; these generally are base-cut-out (BCDE, BDE) sequences, with B-division parallel lamination as the dominant structure. Parallel laminae most commonly concentrate quartz and/or calcispheres vs. lithic clasts or clay, but distinctive millimeter- to centimeter-thick, radiolarian-rich laminae occur in both fine- and coarse-grained Valanginian-Hauterivian turbidites.

AAP turbidites were derived from relatively deep parts of the continental margin (outer shelf, slope, or rise) that lay below the photic zone, but above the calcite compensation depth (CCD). Biogenic components are largely pelagic (calcispheres, foraminifers, radiolarians, nannofossils); lesser benthic foraminifers are characteristic of deep-water (abyssal to bathyal) environments. Abundant nonbiogenic components are mostly clay and clay clasts; smectite is the dominant clay species, and indicates a volcanogenic provenance, most likely the Triassic-Jurassic volcanic suite exposed along the northern Exmouth Plateau.

Lower Cretaceous smarl turbidites were generated during eustatic lowstands and may have reached the abyssal plain via Swan Canyon, a submarine canyon thought to have formed during the Late Jurassic. In contrast to younger AAP turbidites, however, Lower Cretaceous turbidites are relatively fine-grained and do not contain notably older reworked fossils. Early in its history, the northwest Australian margin provided mainly contemporaneous slope sediment to the AAP; marginal basins adjacent to the continent trapped most terrigenous detritus, and pronounced canyon incisement did not occur until Late Cretaceous and, especially, Cenozoic time.
\end{abstract}

\section{INTRODUCTION}

Redeposited sediments, chiefly calcareous turbidites, occur throughout the Mesozoic and Cenozoic sedimentary successions at Site 765 on the Argo Abyssal Plain (Figs. 1,2). The site is less than $75 \mathrm{~km}$ north of the Australian continental margin, which in this region consists of a broad sunken block of continental crust: the Exmouth Plateau. The northern margin of the plateau is steep and is dissected by large submarine canyons, one of which, Swan Canyon, lies due south of Site 765 . These canyons are among the oldest active submarine canyons in the world; Swan Canyon apparently formed immediately after seafloor spreading began along the northwest Australian margin (about $163 \mathrm{Ma}$; Sager et al., this volume) and has been a source of sediment from that time to the present (Exon et al., 1982).

This study describes the oldest turbidites recovered from Site 765: a sequence of Valanginian-Hauterivian age in Cores 123$765 \mathrm{C}-54 \mathrm{R}$ through $-58 \mathrm{R}$, and a sequence of Aptian age in Cores 123-765C-34R through $-40 \mathrm{R}$. Turbidites in both sequences are fully lithified, mostly fine-grained, and have a mixed "smarl" composition (terminology of Dean et al., 1984), dominated by subequal amounts of calcareous and siliceous biogenic material with an admixture of clay and lesser quartz. These sediments provide an opportunity to test models proposed for the description and interpretation of fine-grained turbidites (e.g., Stow and Piper, 1984 ) and illuminate the early history of sediment redistribution along the northwest Australian margin.

\footnotetext{
${ }^{1}$ Gradstein, F. M., Ludden, J. N., et al., 1992. Proc. ODP, Sci. Results, 123: College Station, TX (Ocean Drilling Program).

2 Earth Sciences Board, University of California, Santa Cruz, CA 95064 U.S.A.

${ }^{3}$ Current address: U.S. Geological Survey, 4200 University Drive, Anchorage, AK $99508-4667$ U.S.A.
}

\section{METHODS}

Cores were examined aboard the JOIDES Resolution and subsequently at ODP's Gulf Coast Repository. Petrographic descriptions are based on examination of cores, smear slides, and about 80 thin sections, as well as scanning electron microscope (SEM) and electron dispersive (EDS) analyses of selected samples. Grain size and relative grain percentages were estimated visually by comparison to standardized charts (Dietrich et al., 1982); accuracy of estimation was checked by point-counting several samples and found to be reliable. Clay mineralogy reported herein is based on results of shipboard and shore-based X-ray diffraction (XRD) analyses (Ludden, Gradstein, et al., 1990; Compton and Locker, this volume). Shipboard determinations of carbonate content were supplemented with shore-based analyses of additional samples; $\mathrm{CaCO}_{3}$ content was determined for these samples by total combustion using a LECO CS/125 elemental analyzer after subtraction of organic carbon (which was determined for acid-washed samples by the same method).

\section{VALANGINIAN-HAUTERIVIAN TURBIDITES}

\section{General Features}

Valanginian-Hauterivian smarl turbidites occur through a 33.6-m interval at Site 765 (Sections $123-765 \mathrm{C}-54 \mathrm{R}-4,110 \mathrm{~cm}$, to $-58 \mathrm{R}-2,26 \mathrm{~cm}$; essentially equivalent to Unit VI of Ludden, Gradstein, et al., 1990); recovery of this interval averaged better than $80 \%$ (Fig. 2). Backtracking of sediment units indicates a paleodepth of about $4000 \mathrm{~m}$ for this part of the Site 765 succession (Ludden, Gradstein, et al., 1990), and deposition took place below the CCD. "Background" sediment, interbedded with the turbidites, consists chiefly of reddish-brown, noncalcareous smectitic claystone, with minor thin interlayers of bentonite and radiolarite. Some of the radiolarites may also be turbidites, but others appear 


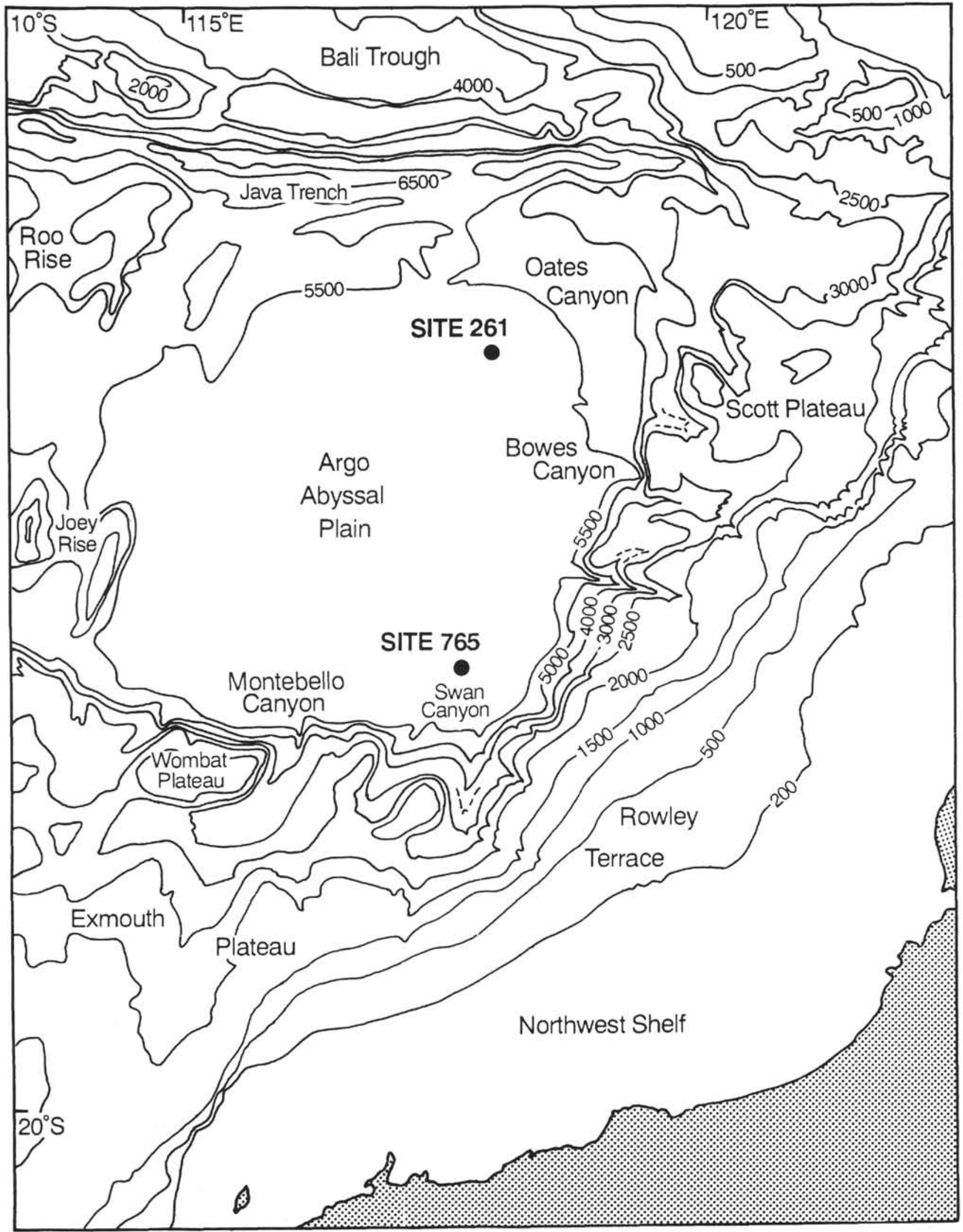

Figure 1. Regional setting and location of Site 765 ; contour interval in meters. 
SITE 765

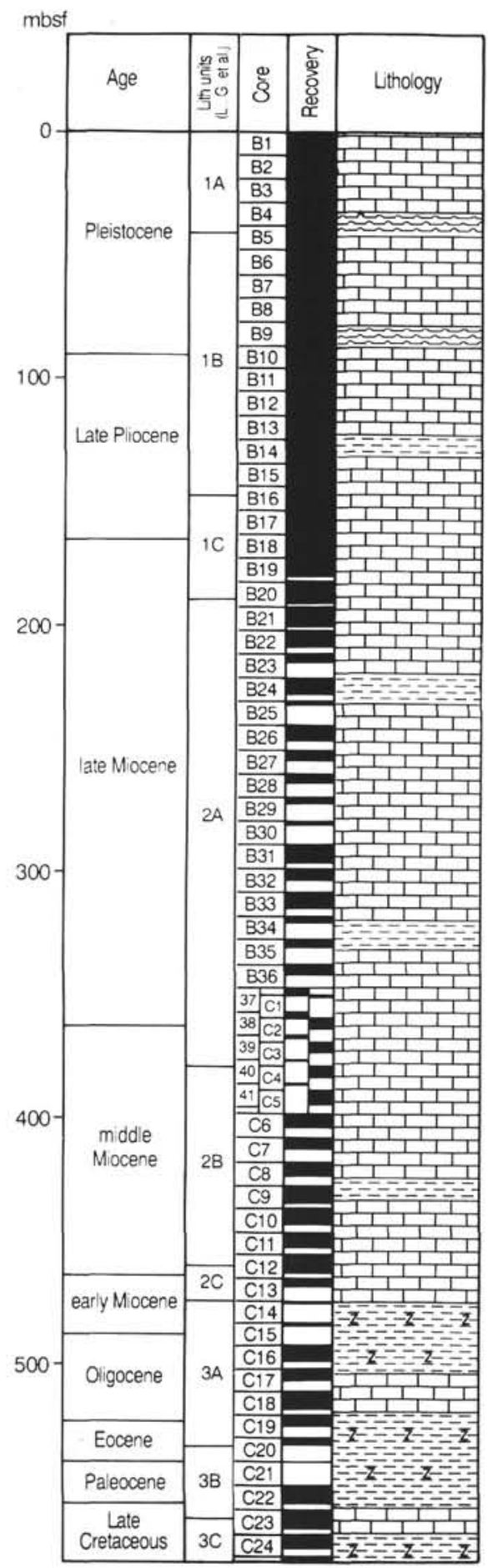

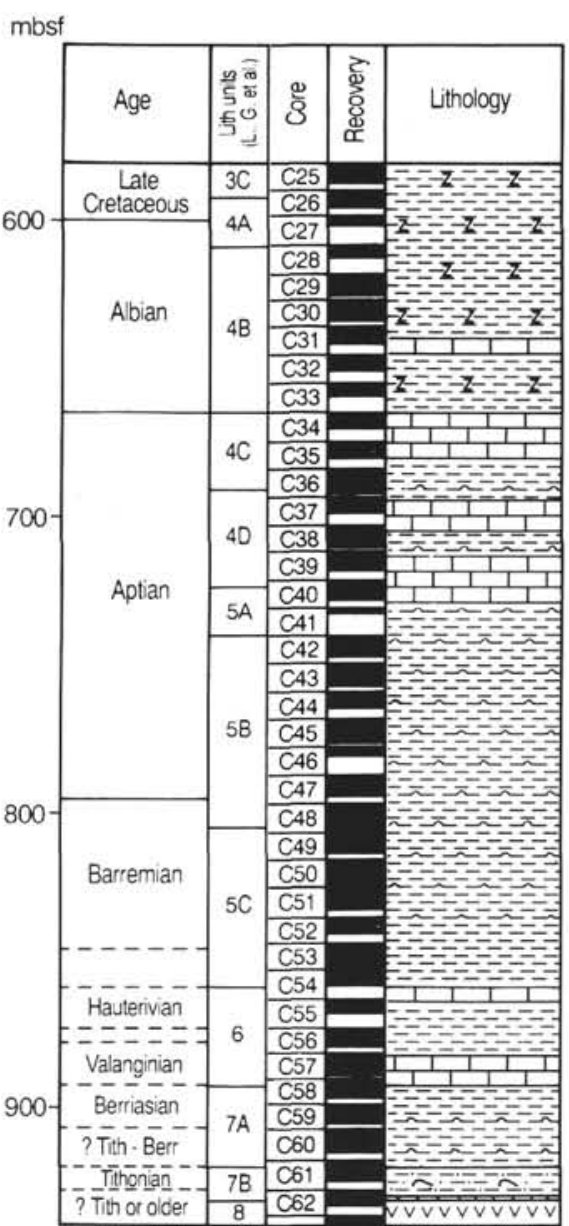

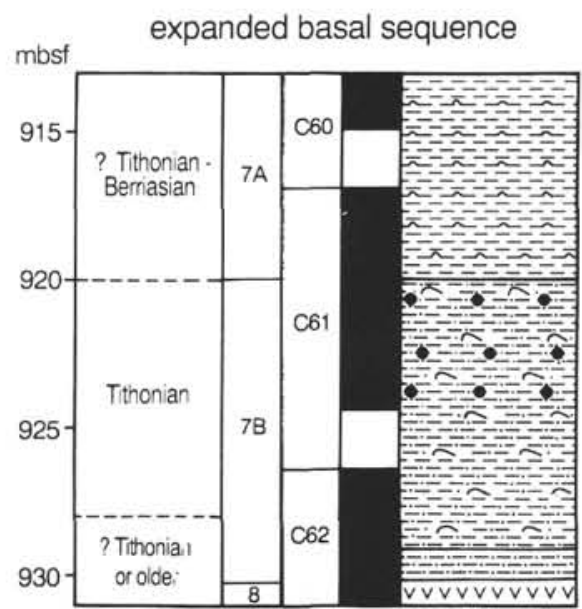

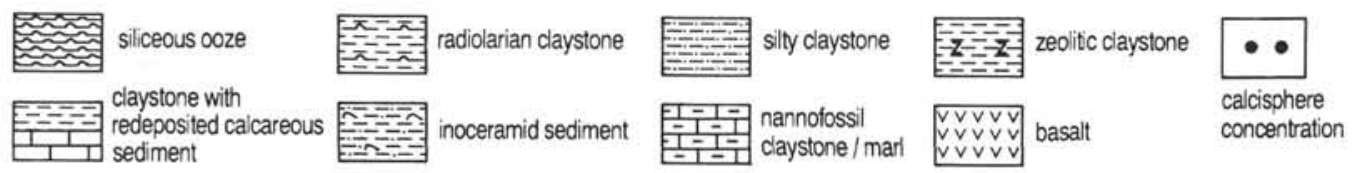

Figure 2. Stratigraphic section at Site 765; turbidites described here occur in Cores 123-765C-34R through $-40 \mathrm{R}$ and -123-765-54R through -58R. Total depths are in meters below the seafloor. 
to have been concentrated by winnowing bottom currents (Ludden, Gradstein, et al., 1990); they are not discussed further here. Smarl turbidites make up just over one-half $(56 \%)$ of Unit VI and are distinguished by the presence of a primary calcareous component. Thus, they can be recognized in the core by a positive reaction with hydrochloric acid. In addition, most of the turbidites are notably lighter in color (turbidite claystones are pink or pale red; sandstones are white, gray, green, or pale brown) than the background claystone (Fig. 3).

Sixty-two distinct turbidites were identified; recovery was complete for more than $90 \%$ of these (top and bottom contacts preserved and no evidence of drilling disturbance throughout). Most $(70 \%)$ are less than $10 \mathrm{~cm}$ thick, but four are thicker than $1.0 \mathrm{~m}$, and one is almost $3 \mathrm{~m}$ thick. One-third of the turbidites consist solely of nannofossil-bearing claystone; another third consist of claystone with minor laminae of silt to fine sand that increase in thickness, number, and grain-size toward the base. These sediments are best described by Stow and Piper's model (1984) for fine-grained biogenic turbidites. The remaining turbidites have clay-sized tops but grade down into several centimeters or more of fine- to coarse-grained sandstone; almost all turbidites thicker than $10 \mathrm{~cm}$ are of this type. They are fairly well described by Bouma's model (1962) for "classical" sandy turbidites.

\section{Fine-Grained Turbidites}

\section{Megascopic Features}

The typical Valanginian-Hauterivian fine-grained turbidite at Site 765 has a gradational top and sharp base (Fig. 4). The shift from background to turbidite sediment is generally marked by a notable lightening in color, from dark reddish-brown to pink or pale red, the appearance of a positive reaction to $\mathrm{HCl}$ acid, and an obvious burrowed horizon. Burrows are mostly Chondrites, decrease downward exponentially, and are filled with noncalcareous clay. The transition between background and turbidite sediment occurs over a few millimeters, or, more rarely, several centimeters. In rare instances, color change is negligible, and discrete bioturbation structures cannot be discerned; the tops of these turbidites are still readily recognized by application of $\mathrm{HCl}$ acid.

The bulk of the turbidite consists of relatively homogeneous nannofossil-bearing claystone. Grading is most evident as a downward increase in the amount of disseminated coarse silt and fine sand. The lowermost zone may contain sharply defined or diffuse parallel laminae, typically 40 to $400 \mu \mathrm{m}$ thick, of silt or fine sand (Fig. 5). The base of the turbidite generally consists of a few millimeters to several centimeters of silt or sand.

\section{Composition}

Clay and calcareous material are the main components of these fine-grained turbidites (Fig. 6). XRD analyses indicate that randomly interstratified illite/smectite (I/S) having less than $10 \%$ interstratified illite layers comprises most of the noncalcareous fraction, along with lesser microcrystalline quartz, discrete illite, and mica (Compton and Locker, this volume; Compton, pers. comm., 1990). Carbonate makes up $20 \%$ to $28 \%$ of all but one sample analyzed (Table 1); the upper part of a thin, pervasively bioturbated, fine-grained turbidite contained only $9 \% \mathrm{CaCO}_{3}$. Carbonate consists dominantly of nannofossils and micrite (nannofossil debris?). Individual nannofossils are randomly oriented rather than aligned within the clayey fabric; this random texture is typical of clayey calcareous turbidites (e.g., Robertson and Bliefnick, 1983). The nannofossil assemblages are relatively diverse and preservation is moderate to good; poorer preservation is seen in samples from thinner turbidites (Fig. 6B). Reworked older nannofossils were not observed, but species indicative of a

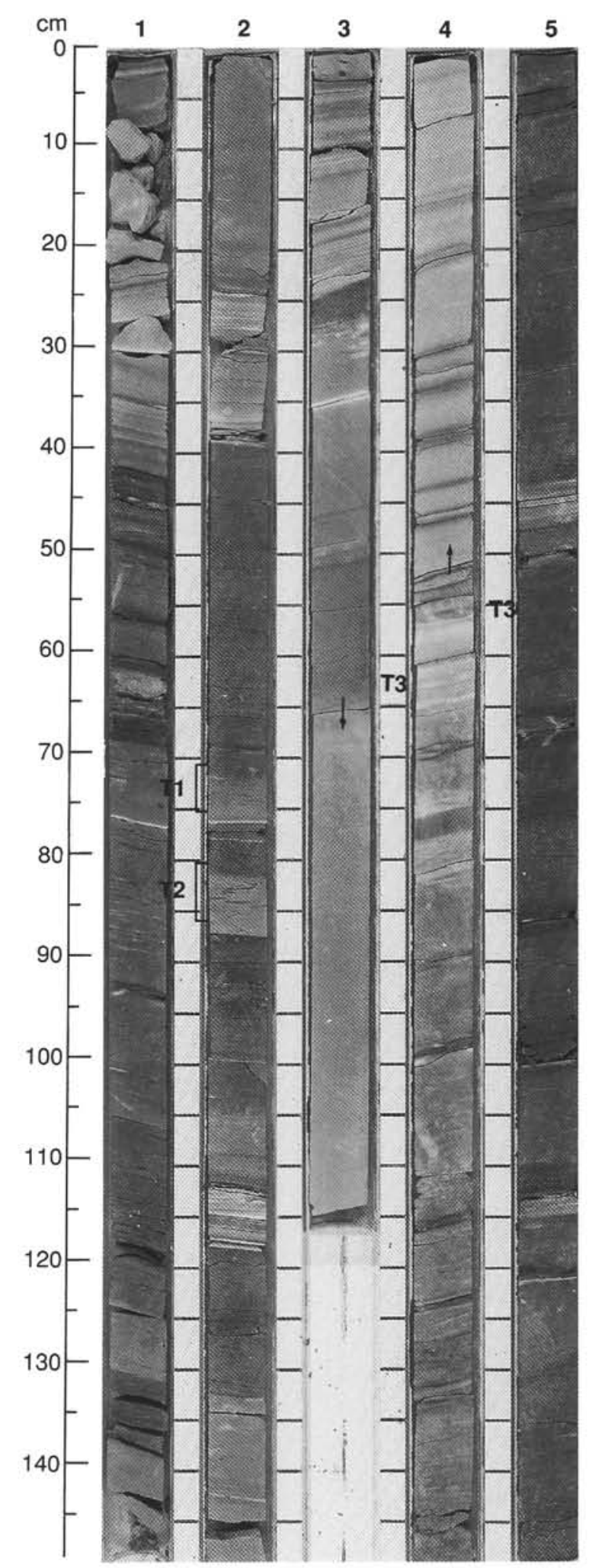

Figure 3. Typical Valanginian-Hauterivian sediments (Sections 123-765C$57 R-1$ through $-57 R-5$ ). Turbidites are lighter colored than the noncalcareous background claystone and range from fine-grained layers a few centimeters thick (i.e., $T_{1}$ and $T_{2}$, Section $2,70-90 \mathrm{~cm}$ ) to intervals of more than $1 \mathrm{~m}$ that grade down into medium-grained sandstone $\left(\mathrm{T}_{3}\right.$, Section $3,65 \mathrm{~cm}$, to Section $4,52 \mathrm{~cm}$ ). The middle part of $T_{3}$ (Section $3,115-150 \mathrm{~cm}$ ) is missing from the photograph because it was removed for geochemical sampling. 


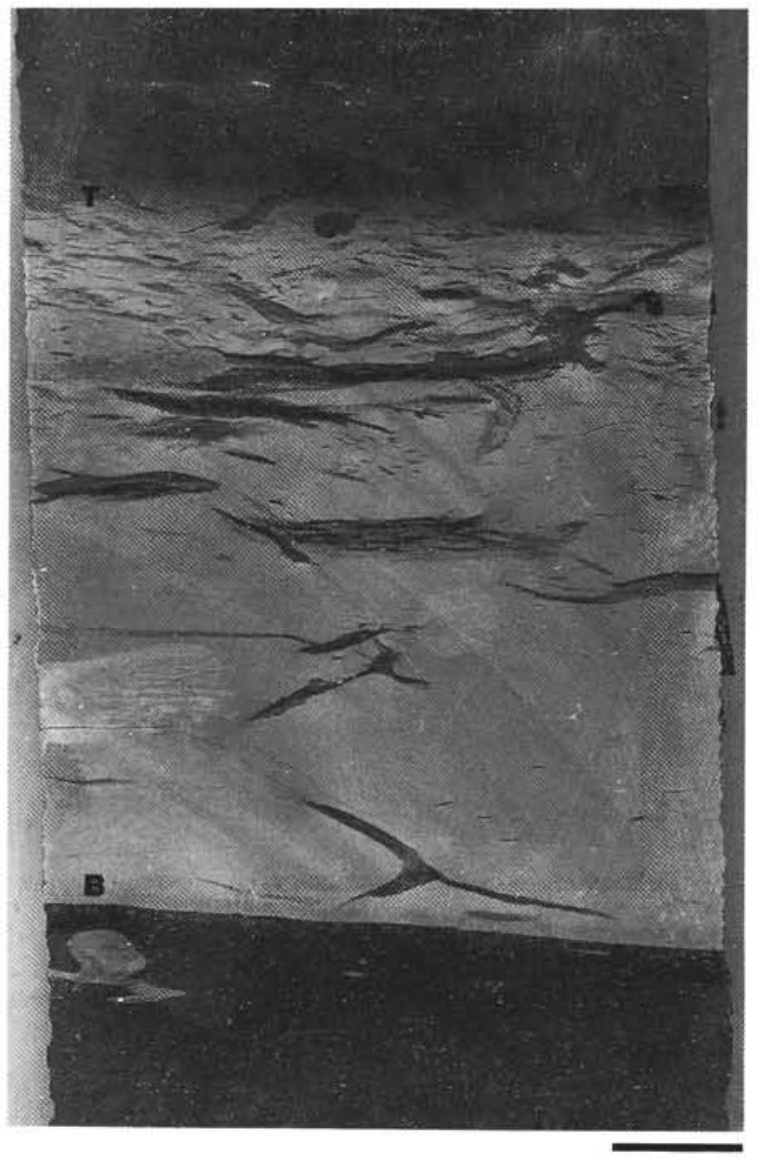

Figure 4. Base-cut-out fine-grained turbidite ( $T_{2}$ in Fig. 3) lacking lower parallel laminated division. Turbidite consists of clay, nannofossils, micrite, and lesser calcispheres and radiolarians; note sharp base (B), gradational top (T), and downward decrease in bioturbation. $123-765 \mathrm{C}-57 \mathrm{R}-2,80-89 \mathrm{~cm}$; scale bar is $1 \mathrm{~cm}$.

nutrient-rich near-shore environment occur in many samples (Dumoulin and Bown, this volume).

Disseminated silt and sand grains consist mainly of calcispheres and quartz, with lesser radiolarians, phosphatic debris, small inoceramid prisms and clay clasts, glauconite, white mica, and opaques. Calcispheres and/or quartz are also the main components of the internal silty laminae and basal silt-sand lags. Radiolarians are uncommon in the upper parts of these turbidites; a sharp contrast often is seen between the radiolarian-poor calcareous claystone at the top of the turbidite and the immediately overlying radiolarian-rich background claystone. However, many turbidites contain a thin (up to $1 \mathrm{~cm}$ ) concentration of radiolarians at or near the base (Fig. 5); similar radiolarian concentrations also can be observed in the coarse-grained turbidites and are discussed further below.

\section{Depositional Models}

Although these smarl turbidites contain more clay than biogenic material, they are best described by the model proposed for fine-grained biogenic turbidites by Stow and Piper (1984), which consists of four main structural divisions (Fig. 7). The lowest (E1) laminated division is hydraulically equivalent to the Bouma D division; in both, silty laminae appear to form as a result of shear sorting and waning current velocities (Hesse and Chough, 1980; Stow and Piper, 1984). About one-half of the Site 765 finegrained turbidites exhibit the complete E1-E/F structural se- quence; the other half are base-cut-out (E2-E/F) turbidites that lack the E1 division. Complete turbidites range from 2 to $27 \mathrm{~cm}$ thick, but average about $7 \mathrm{~cm}$; base-cut-out turbidites are thinner, from 0.25 to $15 \mathrm{~cm}$, averaging about $3 \mathrm{~cm}$.

The detailed structural divisions proposed for nonbiogenic mud and silt turbidites (e.g., Stow and Piper, 1984) cannot be recognized in Site 765 fine-grained turbidites. Stow and Piper's model (1984) for mud turbidites includes eight divisions based primarily on structures within silt laminae; a progression of structures is described, from fading-ripple top in the basal lamina $\left(\mathrm{T}_{0}\right)$, through convolute laminae $\left(\mathrm{T}_{1}\right)$, laminae with climbing ripples $\left(\mathrm{T}_{2}\right)$, parallel laminae $\left(\mathrm{T}_{3}\right)$, discontinuous laminae $\left(\mathrm{T}_{4}\right)$, wispy convolute laminae $\left(\mathrm{T}_{5}\right)$, dispersed silt lenses $\left(\mathrm{T}_{6}\right)$, and, at the top of the turbidite, silt pseudonodules $\left(\mathrm{T}_{7}\right)$. The less-organized nature of turbidites rich in biogenic grains may be a function of the tendency of biogenic material to form less strongly bound flocs than equivalent terrigenous detritus, resulting in a less-complete separation of silt-sized biogenics from clay-sized material (Stow and Piper, 1984).

\section{Coarse-Grained Turbidites}

\section{Megascopic Features}

The coarse-grained Valanginian-Hauterivian turbidites are medium to very thick-bedded $(10 \mathrm{~cm}$ to almost $3 \mathrm{~m})$ and grade upward from medium or fine sandstones to silty claystones identical in structure and composition to the fine-grained turbidites described above. The sandy portion of these turbidites ranges from 3 to $100 \mathrm{~cm}$ thick and typically makes up $40 \%$ of the sequence. The base is always sharp, and sometimes scoured (Fig. $8 \mathrm{~A})$. Parallel lamination is the major structure observed in the sandstones; cross laminae are thin (Fig. 8B) or absent. Sorting is poor; maximum grain size is commonly one to two phi classes above the mean.

\section{Composition}

These sandy turbidites, like the associated finer-grained sediments, have a mixed smarl composition; sand consists mainly of radiolarians, calcispheres, and clayey lithic clasts (Figs. 9 through 12). Radiolarians in these sediments display greater diversity of species but are less well preserved than those in the background claystone (Baumgartner, this volume); they exhibit several types of preservation, including recrystallization to microcrystalline quartz (Fig. 12B), replacement by carbonate (Fig. 11A), and complete dissolution without replacement, leaving behind detailed molds (see "Diagenesis" section, below). Calcispheres show a variety of wall textures and thicknesses (see Fig. 8A of Dumoulin and Bown, this volume). Both radiolarians and calcispheres generally are whole and unflattened and at least partly filled with detrital clay and nannofossils (Fig. 12).

Lithic clasts are primarily claystone and calcareous claystone (Figs. 9, 10) and are invariably larger (by one to three phi classes) than any admixed biogenic grains. The elongate, irregular shape of the lithic clasts indicates that, unlike the bioclasts, they have been strongly flattened and deformed, suggesting that they were only partly consolidated when deposited.

Claystone clasts are similar to the claystone that makes up the background intervals between turbidites; some of the larger clasts contain radiolarian ghosts. Rare claystone clasts are dark brown (rich in organic matter?) and may contain minor amounts of quartz silt. The calcareous claystone clasts are strikingly similar to the calcareous claystone that makes up the fine-grained turbidites and the fine-grained upper parts of the coarse-grained turbidites. Nannofossils, micrite, and calcispheres constitute most of the calcareous component. The carbonate content of layers composed largely of these clasts ranges from $21 \%$ to $33 \%$ (Table 1), similar 
A

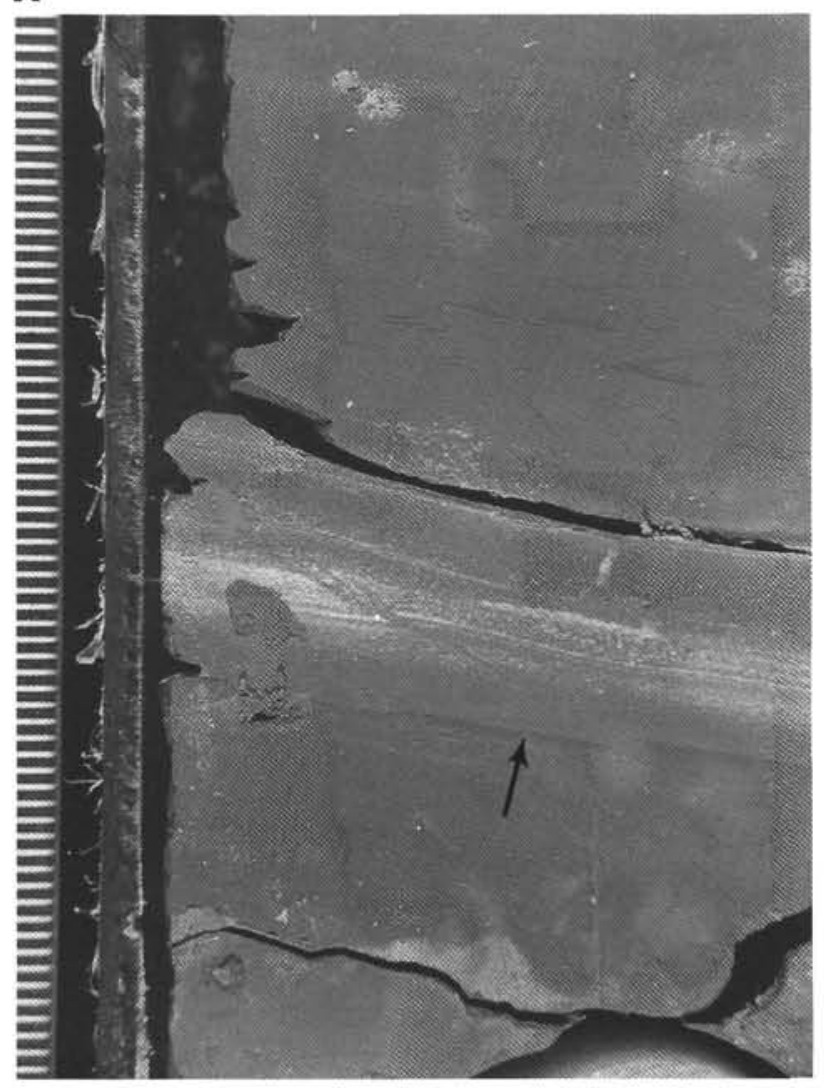

B

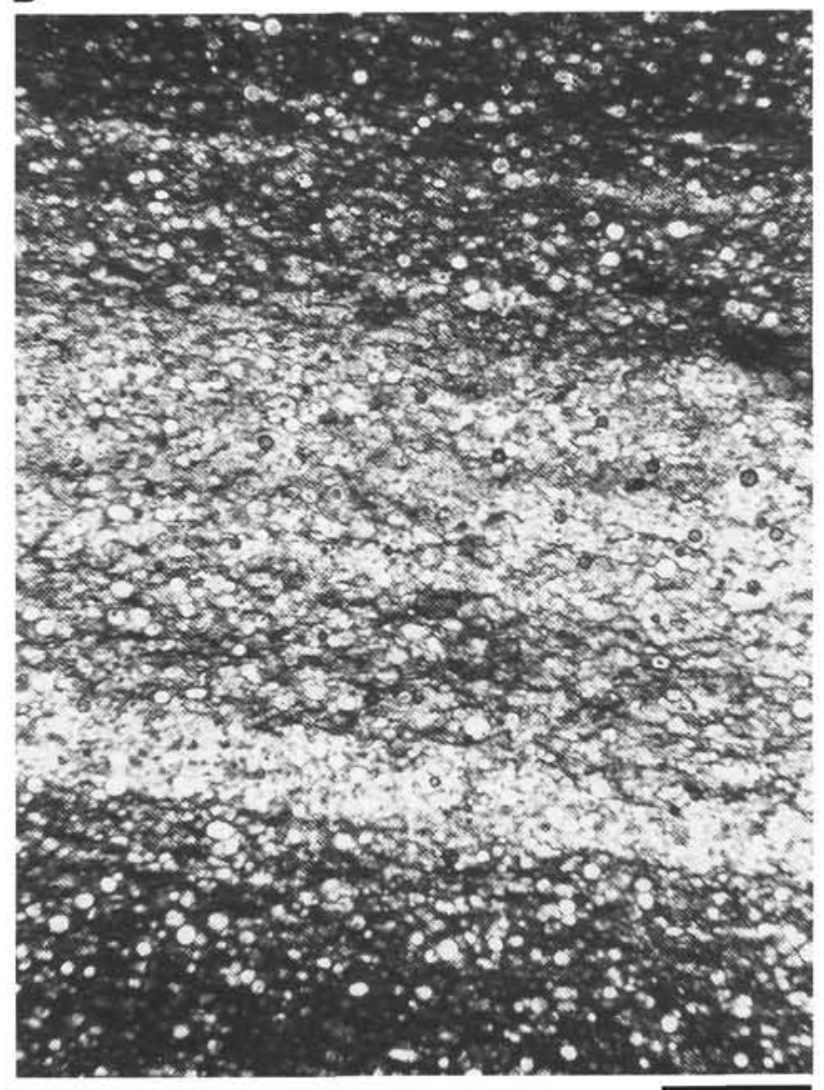

Figure 5. Core photograph (A) and photomicrograph (B) of fine-grained turbidite with slightly diffuse white laminae just above base (arrow); laminae made of radiolarian tests, which are recrystallized to microcrystalline quartz and filled with chalcedony cement (Sample 123-765C-56R-2, 81-87 cm). A. Scale in millimeters. B. Scale bar equals $1 \mathrm{~mm}$.

Table 1. Carbonate content of Valanginian-Hauterivian turbidites and intercalated background sediments at Site 765 .

\begin{tabular}{|c|c|c|c|}
\hline Sample & $\% \mathrm{CaCO}_{3}$ & Sample & $\% \mathrm{CaCO}_{3}$ \\
\hline \multicolumn{4}{|c|}{$\begin{array}{l}\text { NANNOFOSSIL CLAYSTONES (fine-grained turbidites or fine-grained } \\
\text { upper parts of coarse-grained turbidites) }\end{array}$} \\
\hline $123-765 \mathrm{C}-55 \mathrm{R}-3,0 \mathrm{~cm}$ & $21 *$ & $56 \mathrm{R}-3,128 \mathrm{~cm}^{\mathrm{b}}$ & 28 \\
\hline $55 \mathrm{R}-3,7 \mathrm{~cm}$ & $22 *$ & $56 \mathrm{R}-4.9 \mathrm{~cm}^{\mathrm{b}}$ & $22 *$ \\
\hline $55 \mathrm{R}-3,86 \mathrm{~cm}^{\mathrm{a}}$ & $25^{*}$ & $57 \mathrm{R}-3,110 \mathrm{~cm}^{\mathrm{c}}$ & $28 *$ \\
\hline $56 \mathrm{R}-2,120 \mathrm{~cm}$ & $25^{*}$ & $57 \mathrm{R}-3,140 \mathrm{~cm}^{\mathrm{c}}$ & $28 *$ \\
\hline $56 \mathrm{R}-3,71 \mathrm{~cm}^{\mathrm{b}}$ & 26 & $57 \mathrm{R}-4,72 \mathrm{~cm}^{+}$ & 9 \\
\hline \multicolumn{4}{|c|}{ CALCAREOUS SANDSTONES (lower parts of coarse-grained turbidites) } \\
\hline $54 \mathrm{R}-4,110 \mathrm{~cm}^{\mathrm{d} \#}$ & $7 *$ & $56 \mathrm{R}-4,140 \mathrm{~cm}^{\mathrm{b}}$ & $19^{*}$ \\
\hline $54 \mathrm{R}-4,139 \mathrm{~cm}^{\mathrm{d} \#}$ & $15^{*}$ & $57 \mathrm{R}-4,4 \mathrm{~cm}$ c\#\# & 33 \\
\hline $55 \mathrm{R}-4,14 \mathrm{~cm}^{\mathrm{a} \# \#}$ & 21 & $57 \mathrm{R}-6,111 \mathrm{~cm}^{\#}$ & 8 \\
\hline $56 \mathrm{R}-4,109 \mathrm{~cm}^{\mathrm{b}}$ & $15^{*}$ & $58 \mathrm{R}-2,17 \mathrm{~cm}^{\#}$ & 8 \\
\hline \multicolumn{4}{|c|}{ BACKGROUND CLAYSTONES } \\
\hline $55 \mathrm{R}-2,82 \mathrm{~cm}$ & $2 *$ & & \\
\hline $56 \mathrm{R}-2,108 \mathrm{~cm}$ & $1 *$ & $57 \mathrm{R}-7,15 \mathrm{~cm}$ & $1^{*}$ \\
\hline
\end{tabular}

* from Ludden, Gradstein, et al., 1990.

a, b, c , and ${ }^{d}$ samples taken from a single turbidite.

+ from strongly burrowed top of turbidite.

\# sample is rich in clay clasts and contains notable authigenic carbonate.

\#\# sample is rich in calcareous clasts. to the content of fine-grained turbidites and notably higher than layers rich in clay clasts or radiolarians $(7 \%-15 \%)$. Volcanic lithic clasts are rare and were observed only as trace components of three turbidites in the lower half of the unit.

Subordinate components of these sandstones include quartz, inoceramid prisms, calcareous and agglutinated benthic foraminifers, indeterminate calcareous shell debris, phosphatic debris, glauconite, white mica, biotite, plagioclase, microcline, tourmaline, and opaque grains (Fig. 11). Some of the inoceramid prisms contain abundant cylindrical pits filled with red mud that are probably microborings; similar extensively bored inoceramid prisms are a major component of sediment underlying the Valanginian-Hauterivian turbidites at Site 765 (Dumoulin and Bown, this volume). However, many prisms contain no obvious borings. The benthic foraminifers are characteristic of bathyal-to-abyssal water depths (Kaminski, Gradstein, et al., this volume).

Calcareous claystone and claystone clasts make up $40 \%$ to $80 \%$ and $10 \%$ to $30 \%$, respectively, of most Site 765 ValanginianHauterivian sandstones. Relative proportions of the major constituents vary from turbidite to turbidite, but this interturbidite variation is generally less than the compositional variations noted on a scale of millimeters or centimeters within a single turbidite (see "Depositional Models" section, below). Several sandy turbidites near the top and bottom of the turbidite sequence contain mostly claystone and few calcareous clasts; this may be, at least in part, a diagenetic effect (see "Diagenesis" section, below).

The fine-grained (clay-and silt-sized) upper parts of the sandy turbidites have identical composition and microstructures to the fine-grained turbidites described above. In the thickest sandy 
A

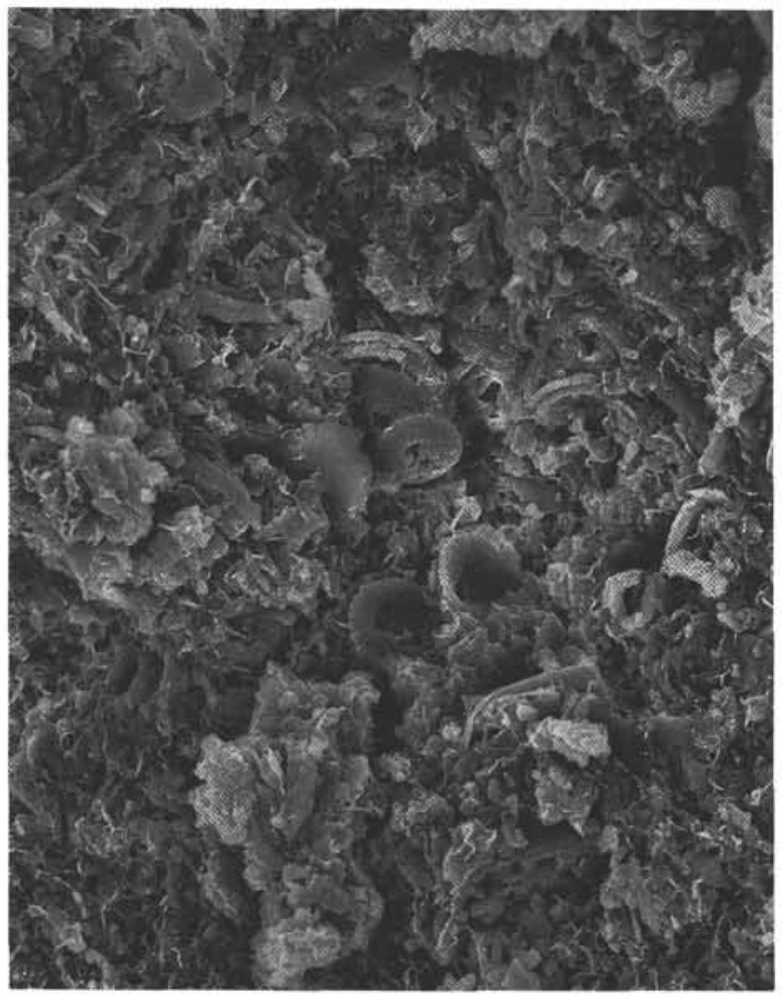

B

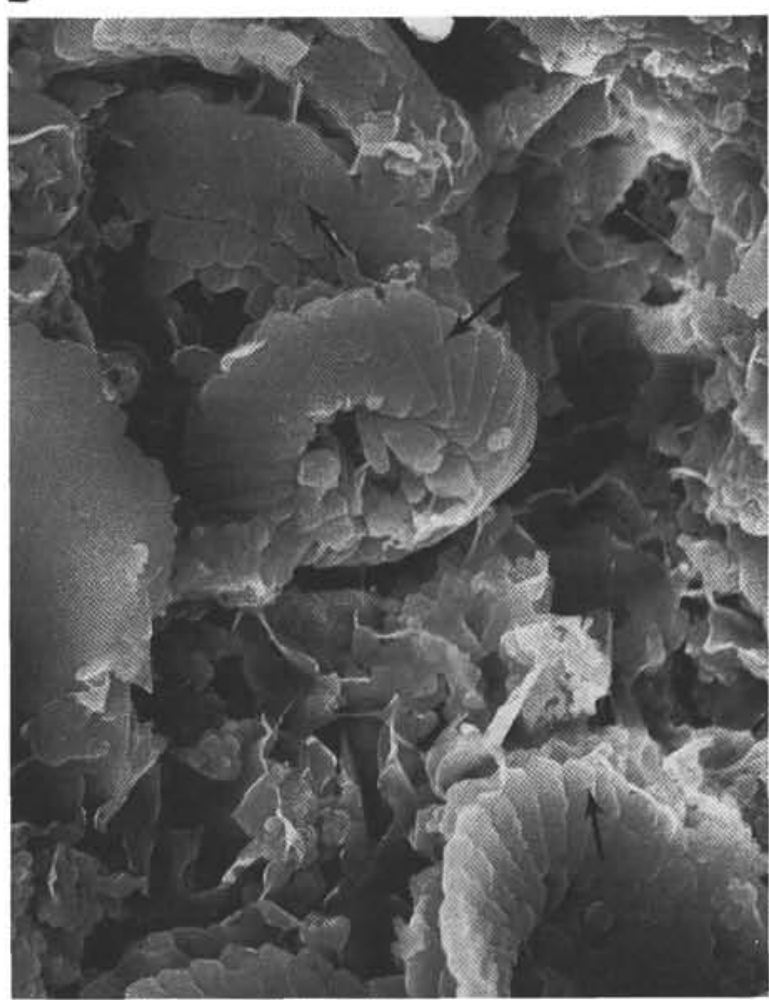

Figure 6. High-magnification SEM photographs of typical fine-grained turbidite (Sample 123-765C-57R-4, 72-76 cm). A. Random orientation of nannofossils (Watznaueria sp.) in clay-rich matrix; scale bar is $10 \mu \mathrm{m}$. B. Detail of A, showing relatively poorly preserved (etched) nannofossils in this thin turbidite; zones of etching indicated by arrows. Scale bar is $2 \mu \mathrm{m}$.

turbidites, the fine-grained upper divisions may extend over 80 cm (i.e., T3 in Fig. 3; clay and silt-sized material occurs from Sections 123-765C-57R-3, $65 \mathrm{~cm}$, to $-57 \mathrm{R}-4,4 \mathrm{~cm}$ ); disseminated coarse silt and fine sand increase downward and form diffuse layers as much as several centimeters thick.

\section{Compositional Layering}

The expression of sedimentary structures in these turbidites is controlled by their inhomogeneous composition. Three distinct types of compositional grading/layering are observed, encompassing a range of scales. The coarsest feature is an upward increase (throughout a single turbidite) in the amount of calcareous lithic clasts at the expense of clay clasts. This is seen both in relatively calcareous turbidites (e.g., Section 123-765C-55R-1, $39-52 \mathrm{~cm}$, calcareous clasts increase from $60 \%$ to $80 \%$ over several centimeters) and in less calcareous turbidites (Section 123-765C-57R-6, 102-121 cm, calcareous clasts increase from $10 \%$ to $20 \%$ over $8 \mathrm{~cm}$ ). In some cases, this gradient is so pronounced that the general aspect of the turbidite is transformed. For example, the basal few centimeters of a thick turbidite in Core $123-765 \mathrm{C}-58 \mathrm{R}$ contain at least $80 \%$ clay clasts, but $10 \mathrm{~cm}$ above the base, clay clasts are at most $20 \%$, and the sediment consists largely of calcareous clasts.

Finer-scale compositional segregation produces the B division lamination so characteristic of these coarse-grained turbidites. In rare cases, laminae are as much as $1 \mathrm{~cm}$ thick and are alternately richer and poorer in calcareous clasts relative to claystone clasts. More commonly, however, B division laminae are thinner and consist primarily of dense grains that are finer (by one or two phi classes) than the lithic clasts in the adjacent laminae. These laminae are 0.1 to $2 \mathrm{~mm}$ thick and spaced 1 to $6 \mathrm{~mm}$ apart. Within

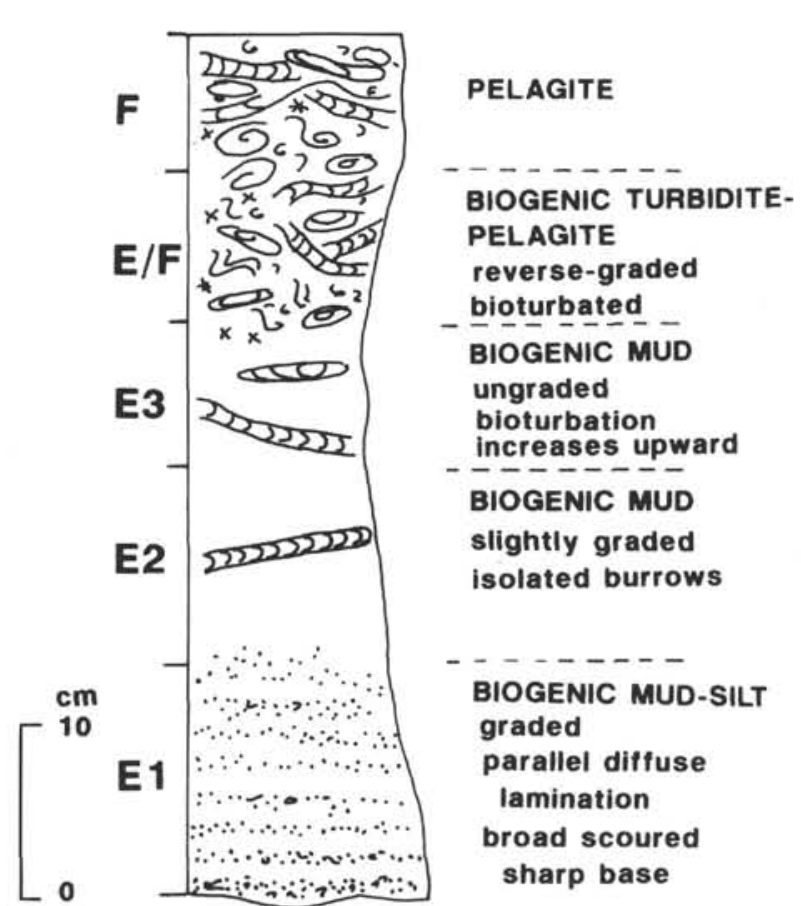

Figure 7. Model of structural divisions in fine-grained biogenic turbidite, from Stow and Piper (1984). 

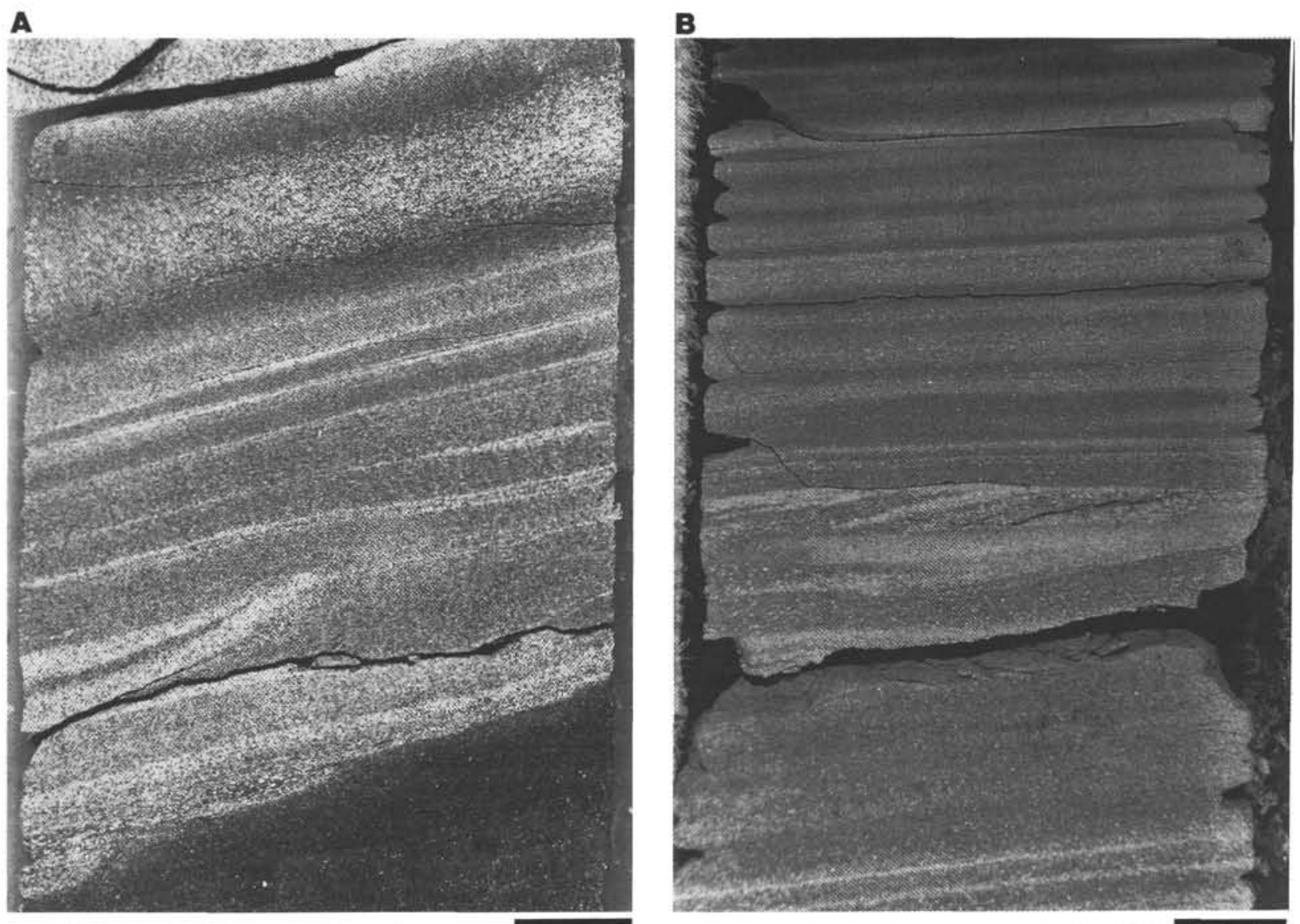

Figure 8. Coarse-grained Valanginian-Hauterivian turbidites. Scale bar is $1 \mathrm{~cm}$. A. Turbidite with scoured base and well-developed B division lamination; thin white laminae are rich in quartz and inoceramid prisms, thick white layer toward top of photograph consists mostly of radiolarians (123-765C-57R-3, $15-24 \mathrm{~cm})$. B. Typical sandy turbidite with well-developed parallel laminae and thin interval of cross-laminae (123-765C-57R-6, 8-17 cm).

a single turbidite, laminae are coarser-grained and generally thicker and more closely spaced toward the base. Quartz and/or calcispheres are the main components; other grains include inoceramid prisms, glauconite, plagioclase, opaques, benthic foraminifers, and phosphatic debris. Calcispheres are particularly abundant in laminae in the most calcareous clast-rich turbidites, whereas quartz dominates laminae in less calcareous turbidites (Fig. 13).

A third, distinctive type of compositional layer in these turbidites is distinctly enriched in radiolarians (Plate 1). These laminae (1 $\mathrm{mm}$ to $1 \mathrm{~cm}$ thick) occur generally within the B division of coarse-grained turbidites (R1-R4 in Fig. 1, Plate 1), but in some cases near the base of the D division. All of the coarse-grained turbidites in Unit VI contain at least one radiolarian-enriched horizon. The thickest turbidites include as many as six laminae spaced 2 to $18 \mathrm{~cm}$ apart; thinner turbidites may contain only a single laminae. Similar laminae also occur within the E1 structural division of some of the fine-grained turbidites described above (Fig. 5).

In the core, the radiolarian-rich laminae are distinctive; they are white, rough-textured, and typically underlain and overlain by brownish sediment (Plate 1, Figs. 2, 3). Thin section and SEM observations indicate that this brown sediment consists of flattened and deformed clay clasts (Plate 1, Fig. 4).

Radiolarians are, at most, a few percent of typical (lithic clast-dominated) sandstone in the Valanginian-Hauterivian coarse-grained turbidites, but form $30 \%$ to $90 \%$ of the radiolarianrich laminae. The individual laminae are not texturally (size) graded, but may show reverse and/or normal grading in radiolarian abundance. Other grains in these laminae include calcispheres, claystone and marlstone clasts, and minor glauconite, inoceramid prisms, and benthic foraminifers.

Thin-section observations of grain size indicate that these radiolarian-rich horizons are punctuations within a single smarl turbidite event, rather than individual thin turbidites themselves. The thick turbidite in Sections 123-765C-56R-3 and -56R-4, for example, contains four discrete radiolarian-rich laminae, each 0.5 to $1 \mathrm{~cm}$ thick (R1-R4, Plate 1, Fig. 1). Both average and maximum sizes of the radiolarians within these laminae increase progressively from the top lamina, R1, to the bottom lamina, R4 (average and maximum radiolarian sizes in $\mathrm{R} 1$ are 80 and $160 \mu \mathrm{m}$, respectively, and in R4 are 160 and $400 \mu \mathrm{m}$; intermediate values occur in R3 and R4). Similarly, the average and maximum sizes of the lithic clasts in the sediment separating the radiolarian-rich laminae also increase steadily, from 120 and $160 \mu \mathrm{m}$, respectively, just below the R1 horizon, to $400 \mu \mathrm{m}$ and $1.2 \mathrm{~mm}$ at the base of the turbidite.

\section{Depositional Models}

Unit VI sandy turbidites are best described according to Bouma's model (1962) and represent exclusively base-cut-out $\mathrm{B}(\mathrm{C}) \mathrm{DE}$ sequences. The $\mathrm{B}$ and $\mathrm{D}$ divisions of parallel sandy and silty lamination, respectively, are well developed, but the intermediate $\mathrm{C}$ division (cross lamination) is generally thin (a few centimeters at most) and sometimes absent. The $\mathrm{B}$ and $\mathrm{D}$ divisions, in contrast, may be 20 to $40 \mathrm{~cm}$ thick in the thickest 
A

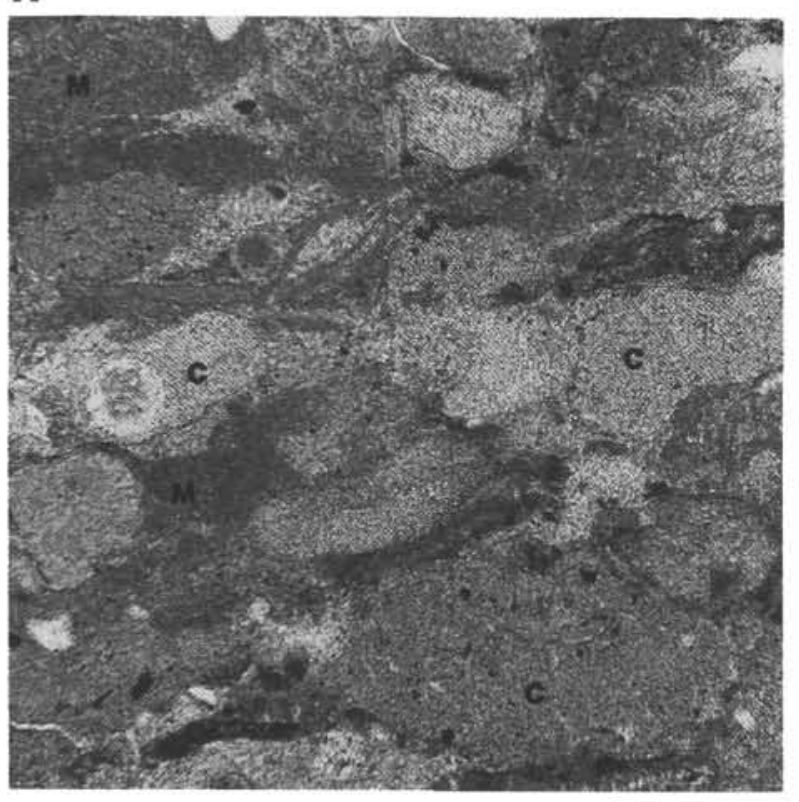

\section{B}

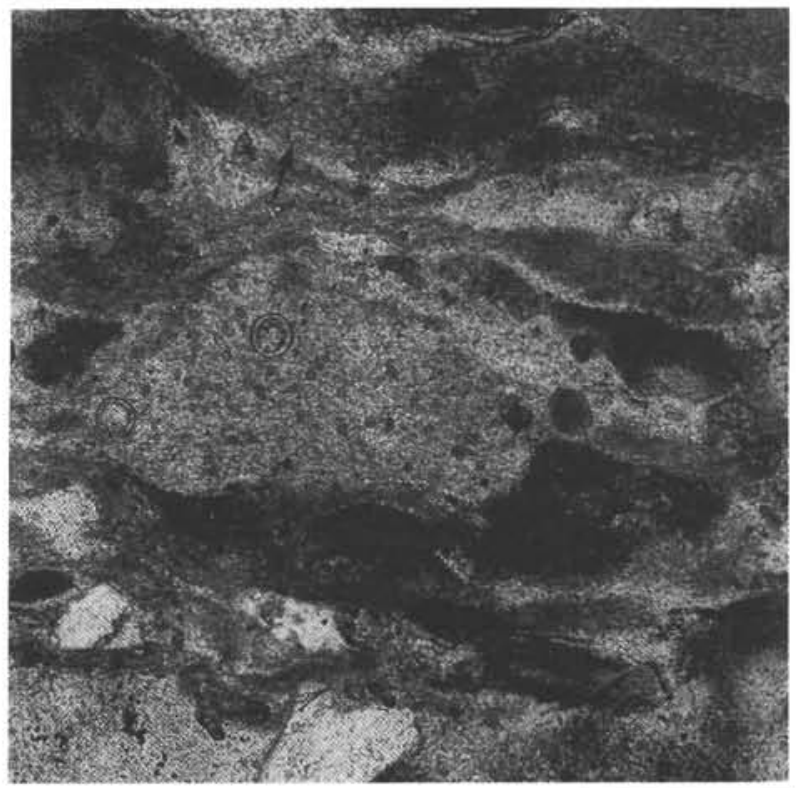

Figure 9. Photomicrographs of sandy turbidite microtextures; scale bars equal $0.2 \mathrm{~mm}$. A. Medium-grained sandstone rich in lithic clasts, mainly claystone (C) and lesser marlstone (M); some of the claystone clasts contain radiolarian ghosts or quartz or opaque silt (Sample 123-765C-56R-4, 148-149 cm). B. Variety of marlstone clasts; clast in center contains calcispheres and nannofossils. Arrow indicates clast which contains abundant authigenic carbonate (mostly rhodochrosite) (Sample 123-765C-56R-4, 141-144 cm).

A

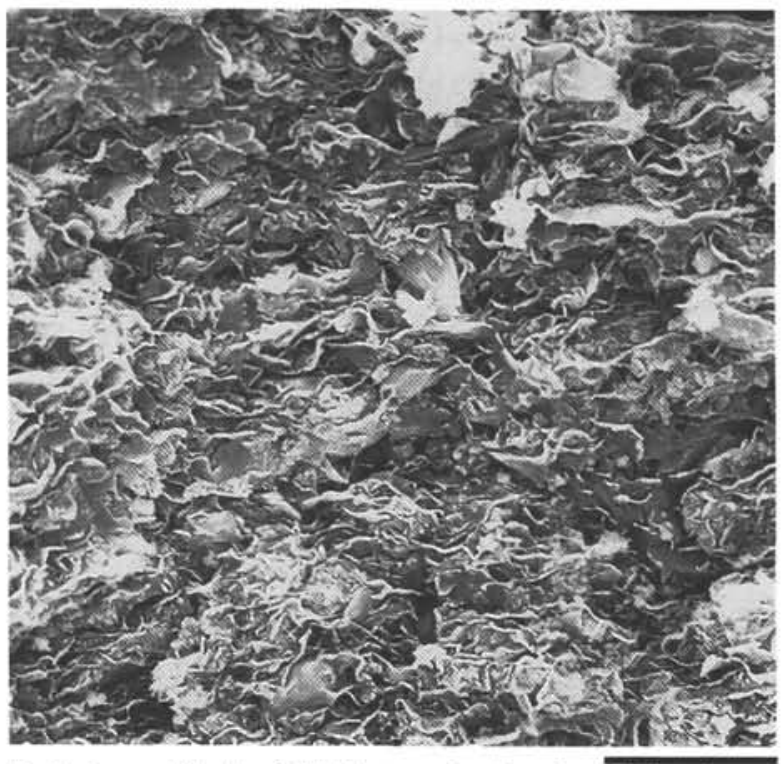

B

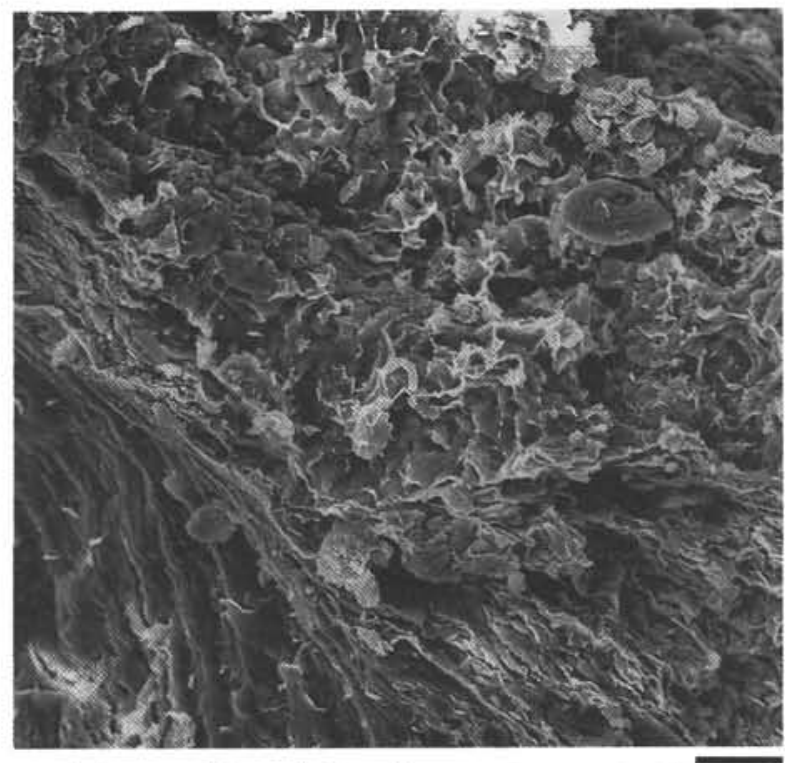

Figure 10. High-magnification SEM photographs of sandy turbidite microtextures; scale bars equal $5 \mu \mathrm{m}$. A. Noncalcareous claystone clast from sandstone shown in 9A. B. Marlstone clast (Sample 123-765C-57R-2, 25-29 cm).

turbidites. A poorly developed C-division has been observed in other pelagic carbonate turbidites (e.g., Scholle, 1971a; van Tassell, 1981) and might reflect simply the rarity of calcareous material of the correct size and density to produce climbing ripples during lower flow regime conditions (Pickering et al., 1989). Because radiolarian-rich layers in these turbidites occur within both B and D divisions, it would appear that radiolarian tests can be hydraulically concentrated by upper and lower flow regime processes.

Biogenic turbidites have been reported to display both upward increases and upward decreases in carbonate content (Stow and Piper, 1984). Analyses from different levels within ValanginianHauterivian turbidites generally show a modest increase upward, although samples from a turbidite rich in authigenic carbonate 
A

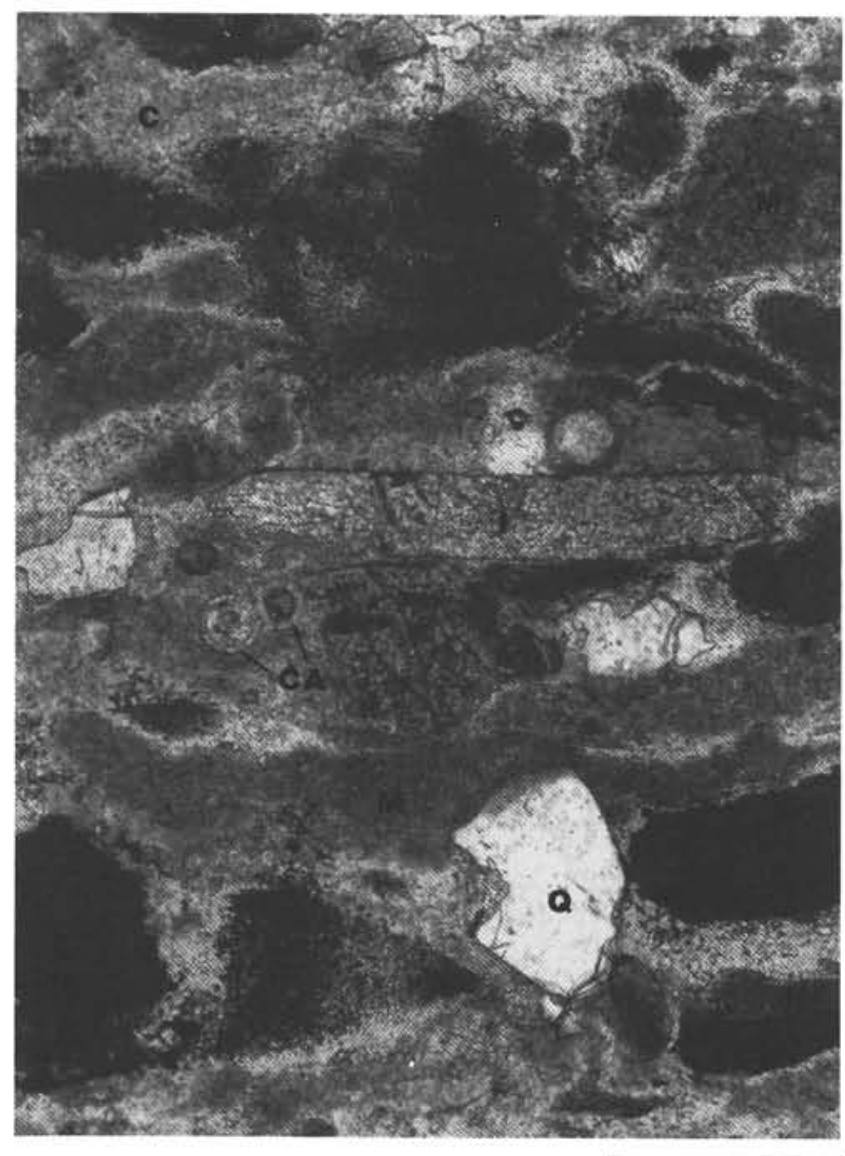

B

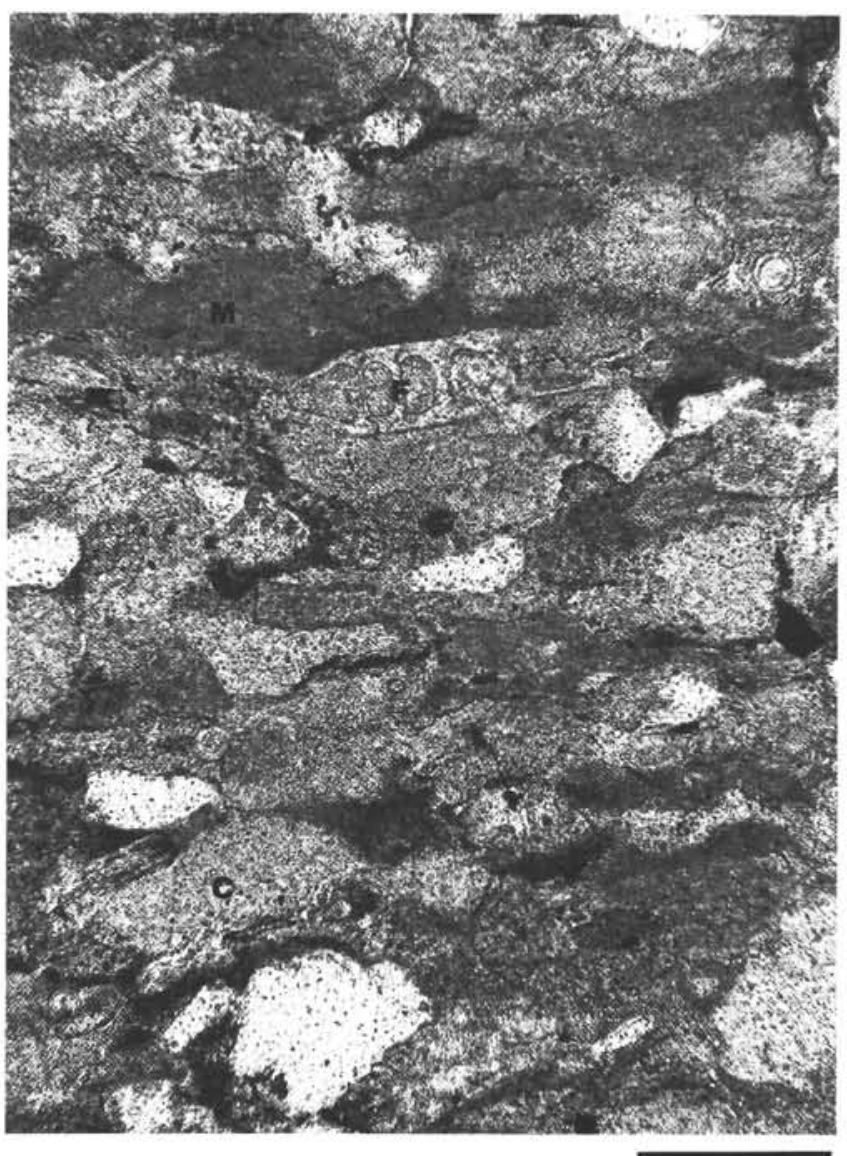

Figure 11. Photomicrographs of sandy turbidite microtextures; scale bars equal $0.2 \mathrm{~mm}$ (Sample 123-765C-56R-4, 148-149 cm). Clasts are mainly claystone (C) and marlstone $(\mathrm{M})$, but include inoceramid prisms $(\mathrm{I})$, a benthic foraminifer $(\mathrm{F})$, angular quartz $(\mathrm{Q})$, calcispheres $(\mathrm{CA})$ and a radiolarian $(\mathrm{R})$ replaced by manganese carbonate.

show the opposite trend (Table 1). In all cases, differences among values are near the range of experimental error (5\% for LECO analyses). Little difference in carbonate content can be seen between sandstone and claystone samples from the same turbidite.

\section{Diagenesis}

In contrast to turbidites rich in shallow-water calcareous components with unstable mineralogy (such as aragonite), the Valanginian-Hauterivian smarl turbidites have a relatively low "diagenetic potential” (terminology of Schlanger and Douglas, 1974). Like other turbidite sequences rich in pelagic carbonate (e.g., Upper Cretaceous flysch of the Apennines described by Scholle, 1971b), Unit VI turbidites have been lithified largely through compaction rather than cementation (Figs. 6,11, and 12). Other diagenetic effects noted in these sediments and described below include occurrence of authigenic crystals of manganese carbonate and barite, and recrystallization and replacement of radiolarian tests.

Authigenic carbonate occurs throughout the ValanginianHauterivian turbidites and is found in the intercalated background claystones as well. Virtually every Unit VI thin section and smear slide examined contained disseminated euhedral carbonate crystals (Fig. 14). Crystals are pale brown in hand sample and yellow to brown in thin section; most have an equant, rhombic form, but some are rectangular and rhomboid. Most crystals are small, 3-16 $\mu \mathrm{m}$, rarely to $40 \mu \mathrm{m}$, but intergrown crystal aggregates to several hundred micrometers in diameter occur locally.

Authigenic carbonate was noted in initial shipboard studies of these sediments, but was not subjected to XRD analysis. However, petrographically similar diagenetic carbonate rhombs in overlying Unit V claystones were analyzed and identified as rhodochrosite and dolomite, although it was noted that XRD patterns did not always match the expected patterns and thus mixed $\mathrm{Mg}$ - and $\mathrm{Mn}$-carbonate minerals were thought to be present (Ludden, Gradstein, et al., 1990).

EDS analyses were performed on carbonate rhombs from throughout Unit VI sediments during the course of this study; rhombs from background claystone and from fine-grained and coarse-grained turbidites were analyzed. All samples contained both $\mathrm{Mn}$ and $\mathrm{Ca}$; semi-quantitative analyses of EDS spectra indicate that most crystals are probably rhodochrosite, as $\mathrm{Mn}$ is 5 to 20 times more abundant than $\mathrm{Ca}$. However, some crystals appear to contain roughly equal amounts of $\mathrm{Ca}$ and $\mathrm{Mn}$ and are likely kutnahorite, $\mathrm{CaMn}\left(\mathrm{CO}_{3}\right)_{2}$, a dolomite-like compound (Deer et al., 1965). Mg was rarely detected in the EDS analyses performed and was never found in more than trace amounts. Thus, most of the authigenic carbonate within Unit VI sediments appears to be rhodochrosite.

Thin section, smear slide, and SEM observations delineate the occurrence of manganese carbonate within these sediments. Rhombs are disseminated throughout the background claystones 
A

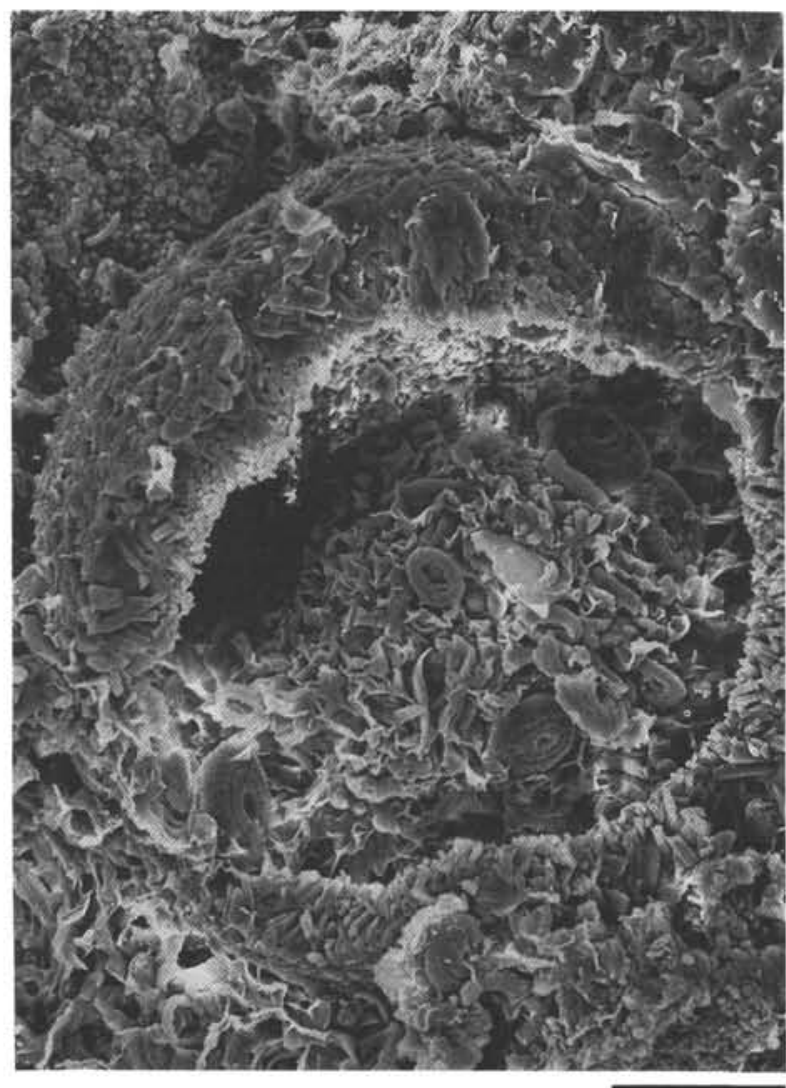

B

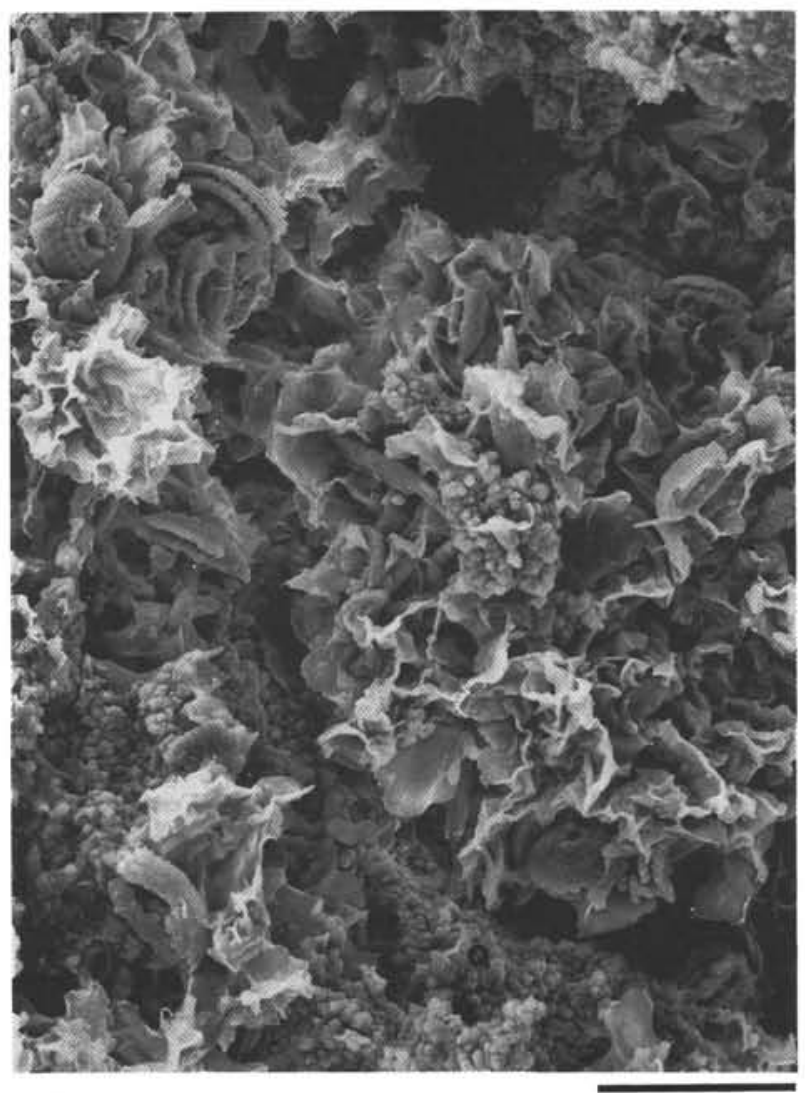

Figure 12. High-magnification SEM photographs of sandy turbidite microtextures; scale bars equal $10 \mu \mathrm{m}$ (Sample $123-765 \mathrm{C}-57 \mathrm{R}-2,25-29 \mathrm{~cm}$ ) $\mathrm{A}$. Calcisphere partially filled with detrital clay and nannofossils. B. Detail of radiolarian skeleton recrystallized to microcrystalline quartz (Q) and filled with detrital clay and nannofossils.

and fine-grained turbidites and occur in the clay-rich clasts and clayey matrix of the coarser-grained turbidites. Rhombs also coalesce into larger spherical-to-ovoid masses in the sandstones; by their size and shape, these masses appear to be replaced radiolarians and/or calcareous claystone clasts (Fig. 14A).

Manganese carbonate makes up $5 \%$ or less, generally $1 \%$ or less, of most samples. It appears to be slightly more abundant in noncalcareous background claystones than in most turbidites and is particularly notable in clay-filled burrows in the upper parts of fine-grained turbidites. In most Unit VI turbidites, crystals of authigenic carbonate occur adjacent to well-preserved nannofossils (Fig. 14B) and there is little evidence of extensive dissolution of calcite. However, manganese carbonate is most abundant in the lowest and highest Valanginian-Hauterivian smarl turbidites, where it fills calcispheres, replaces matrix and many clasts and forms $10 \%$ to $20 \%$ of the sediment. These turbidites also contain the fewest and most poorly preserved nannofossils and have the lowest overall carbonate contents (Table 1); in these samples, manganese carbonate may have formed at the expense of original calcareous components such as nannofossils. Jakobsen and Postma (1989) found that finely crystalline manganese carbonate replaced calcite shell fragments in Baltic marine muds.

Authigenic formation of rhodochrosite and other manganese carbonate minerals is generally associated with suboxic and anoxic decomposition of organic matter, but may occur in environments ranging from post-oxic to sulfidic and methanic (Jakobsen and Postma, 1989). Isotopic data from manganese carbonates at Site 765 suggest that they formed early within the sulfate reduction zone, but were later recrystallized at deeper burial depths
(Compton, this volume). Both the biogenic composition of the Site 765 turbidites and their intermittent accumulation appear to have facilitated formation of manganese carbonate minerals. The turbidites provide a source of $\mathrm{Ca}$ and organic matter to the abyssal plain environment, and their sudden influx preserves Mn oxides formed at the sediment/seawater interface during periods of pelagic (interturbidite) sedimentation (Hein and Koski, 1987; Compton, this volume). These oxides are then reduced, remobilized, and diffuse through the sediment to precipitate as manganese carbonate.

Authigenic barite occurs sparsely but persistently in Unit VI sediments as large (to $300 \mu \mathrm{m}$ ) poikilotopic euhedra. It is especially abundant filling radiolarian tests or molds, in noncalcareous claystone-filled burrows in fine-grained turbidites, and in quartzor calcisphere-rich layers in coarse-grained turbidites. Barite is widespread in deep-sea sediments and can be derived from biogenic material during early diagenesis (Kennett, 1982); it may be especially abundant where carbonate- and silica-rich sediments are closely associated (Murchey et al., 1987).

Radiolarian tests are variously preserved in the ValanginianHauterivian turbidites. Where tests were most densely concentrated (as laminae within fine- and coarse-grained turbidites), they are largely recrystallized to microcrystalline quartz and may be filled with sheaves of chalcedonic cement (Plate 2, Figs. 1-3). Where tests were more sparsely distributed, particularly in the upper parts of the fine-grained turbidites, most have been dissolved, leaving behind detailed molds (Plate 2, Fig. 4). Finely crystalline rhombic carbonate fills some molds; EDS analyses of this carbonate indicate it is manganese-rich rhodochrosite. 
A

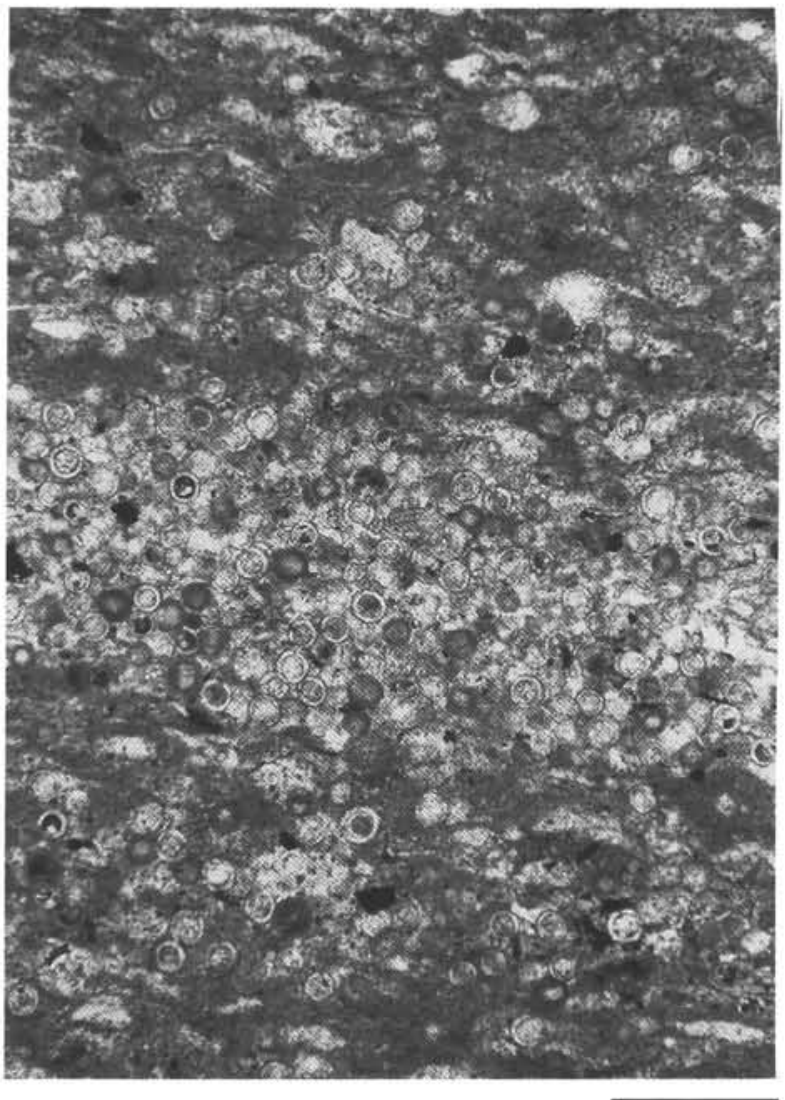

B

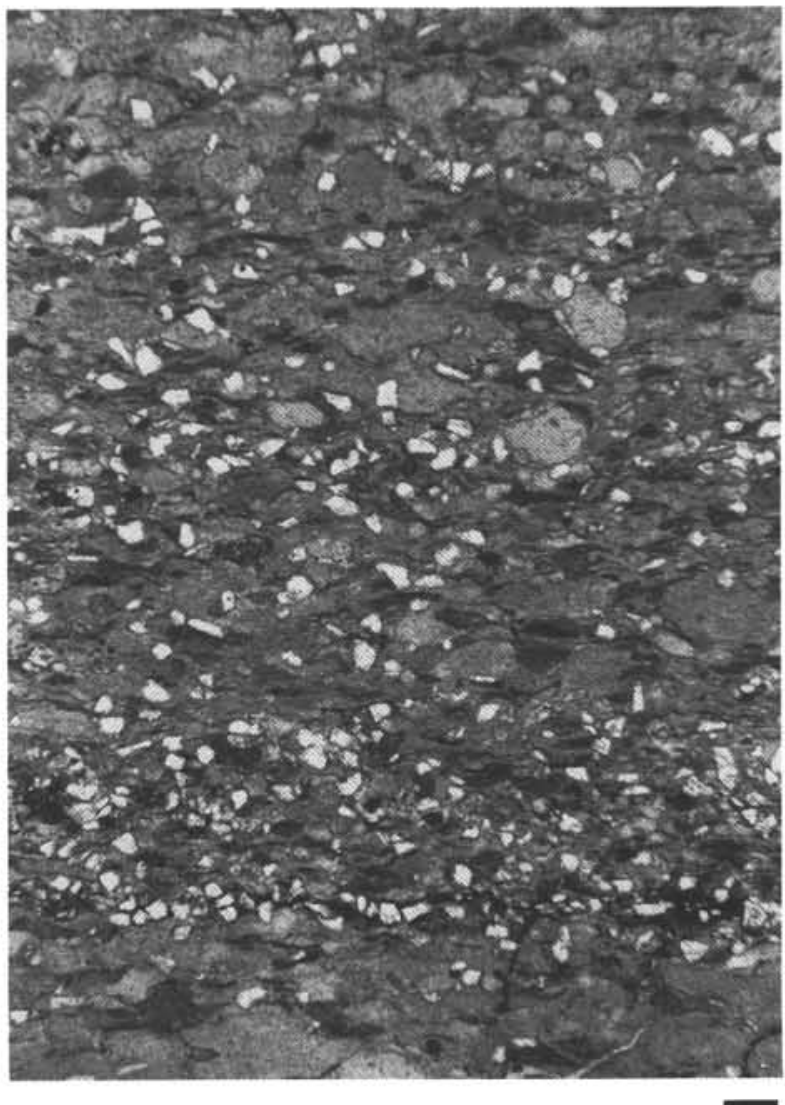

Figure 13. Photomicrographs of B division lamination in sandy turbidites; scale bars equal $0.2 \mathrm{~mm}$. A. Concentrated calcisphere-rich lamina in sandstone composed mainly of marlstone clasts and lesser claystone clasts (Sample 123-765C-57R-4, 4-7 cm). B. Relatively diffuse quartz-rich laminae in sandstone composed mainly of claystone clasts and lesser marlstone clasts (Sample 123-765C-56R-1, 114-116 cm).

A

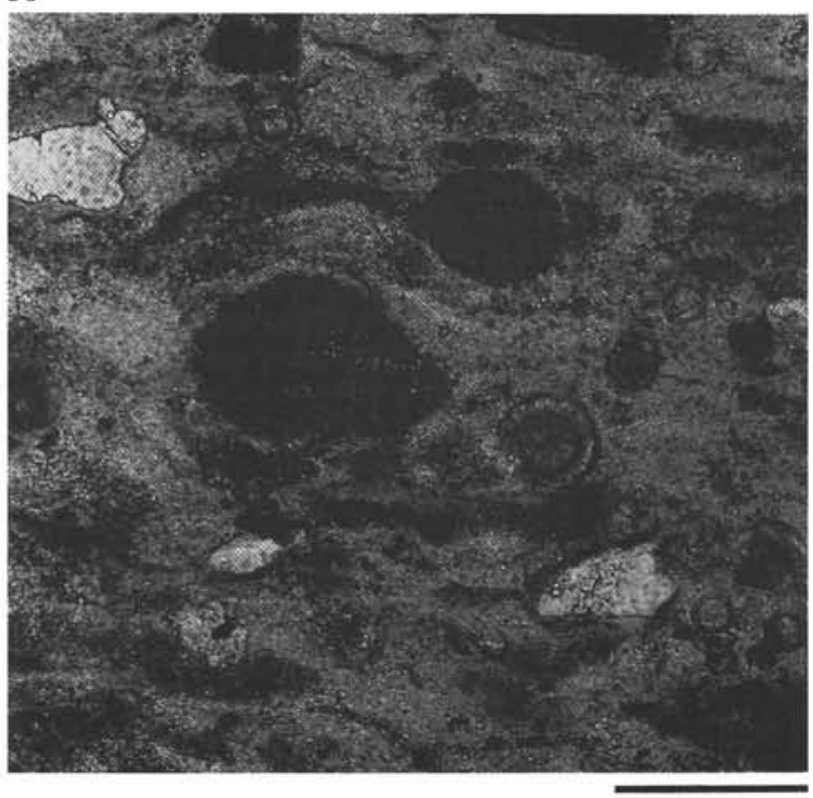

B

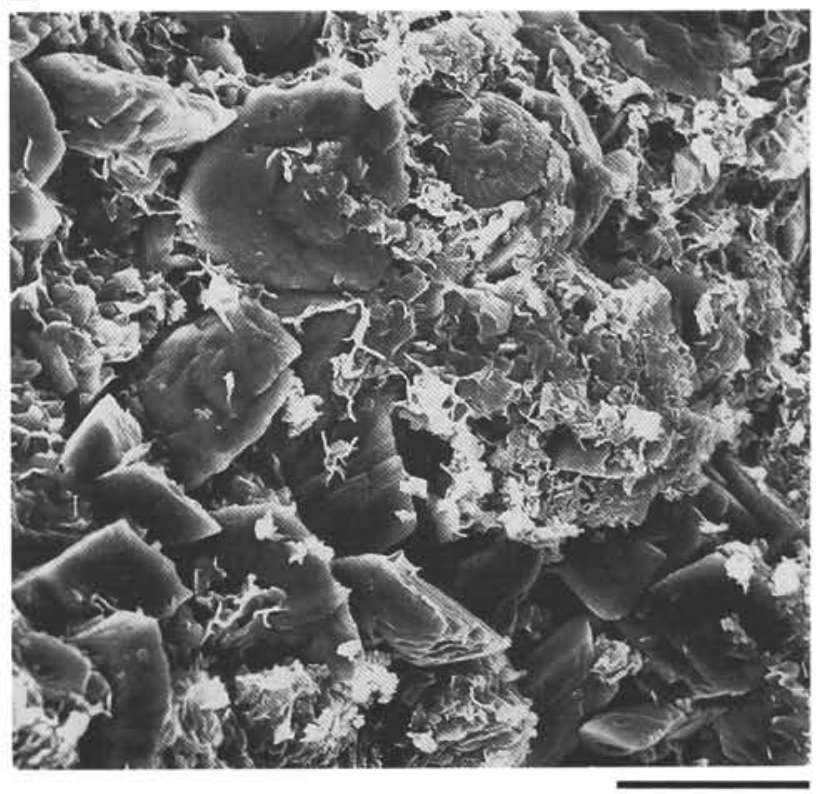

Figure 14. Authigenic carbonate in Valanginian-Hauterivian turbidites. A. Photomicrograph of ovoid concentrations (R) of small carbonate rhombs (kutnahorite). Sample 123-765C-54R-4, 135-136 cm; scale bar is $0.15 \mathrm{~mm}$. B. High-magnification SEM photograph of a marlstone clast from Sample 123-765C-56R-4, $148-149 \mathrm{~cm}$, showing well-preserved nannofossil (Watznaueria sp.) adjacent to rhombs of kutnahorite; scale bar is $10 \mu \mathrm{m}$. 


\section{APTIAN TURBIDITES}

\section{General Features}

Turbidites having many textural and compositional similarities to the Valanginian-Hauterivian turbidites described above occur $120 \mathrm{~m}$ higher in the section at Site 765 (Fig. 2). These turbidites are of Aptian age and occur through an interval of 60 $\mathrm{m}$ in Cores 123-765C-34R through -40R (Subunits IVC, IVD, and the uppermost part of VA of Ludden, Gradstein, et al., 1990); overall recovery of this interval was about $70 \%$. The intervening Hauterivian-Aptian section contains less than $2 \%$ recognized turbidites and consists mainly of noncalcareous claystone, reddish-brown in the lower cores but becoming greenish-gray upward. The few sandy turbidites that occur are thin-bedded (less than $4 \mathrm{~cm}$ ) radiolarites and thin- to medium-bedded (less than 25 $\mathrm{cm}$ ) mixed sediments rich in quartz and/or claystone clasts in addition to radiolarians. Primary (nondiagenetic) calcareous material is exceedingly rare in these Hauterivian-Aptian turbidites and entirely absent from most. However, sedimentation rates for this interval are high $(20 \mathrm{~m} / \mathrm{m} . \mathrm{y}$.), and it seems likely at least some of the noncalcareous claystone has been redeposited (Dumoulin and Bown, this volume).

The younger Aptian turbidites (Cores 123-765C-34R through $-40 \mathrm{R}$ ) contain abundant calcareous bioclasts in addition to siliceous bioclasts and terrigenous components. Although the proportions of these components vary from one turbidite to another, all turbidites in this interval have a mixed composition; contrary to initial shipboard conclusions (Ludden, Gradstein, et al., 1990), there is no distinct subpopulation of noncalcareous (siliciclastic) turbidites.

Turbidites constitute more than $80 \%$ of the sediment in this interval and are intercalated with noncalcareous, mainly olive gray smectitic claystone; deposition took place below the CCD at depths of almost $5000 \mathrm{~m}$ (Ludden, Gradstein, et al., 1990). At least 63 discrete turbidites can be discerned. About one-third are less than $10 \mathrm{~cm}$ thick, but six are thicker than $1 \mathrm{~m}$, and three of these are thicker than $3 \mathrm{~m}$. Roughly one-half of the turbidites in this interval are fine-grained (dominantly clay- and silt-sized); these sediments are best described using Stow and Piper's biogenic turbidite model (1984; Fig. 7). The other turbidites generally have a claystone upper division, but grade downward into fine- or medium-grained sandstone and can be described using Bouma's sandy turbidite model (1962). Sandy turbidites become increasingly abundant upsection and dominate Cores $123-765 \mathrm{C}-34 \mathrm{R}$ and $-35 \mathrm{R}$.

The Aptian turbidites are mostly green to greenish-gray and distinctly lighter in color than the background claystone (Fig. 15). The sandy lower divisions may be pale grayish-brown or white. Cores $123-765 \mathrm{C}-34 \mathrm{R}$ and $-35 \mathrm{R}$ contain several dark gray to black turbidites that are less calcareous and richer in organic material than other turbidites in this interval.

\section{Fine-Grained Turbidites}

\section{Megascopic Features}

The Aptian fine-grained turbidites are much like the Valanginian-Hauterivian fine-grained turbidites described above. They have gradational, burrowed tops and sharp bases; burrows decrease and disseminated silt and sand increase downward. Most contain diffuse parallel laminae of fine sand and silt that increase in thickness (up to a few millimeters) and are more closely spaced near the base (Plate 3, Figs. 1, 2).

\section{Composition}

Clay, nannofossils, and micrite are the dominant components. The clay is chiefly I/S with less than $10 \%$ interstratified illite and

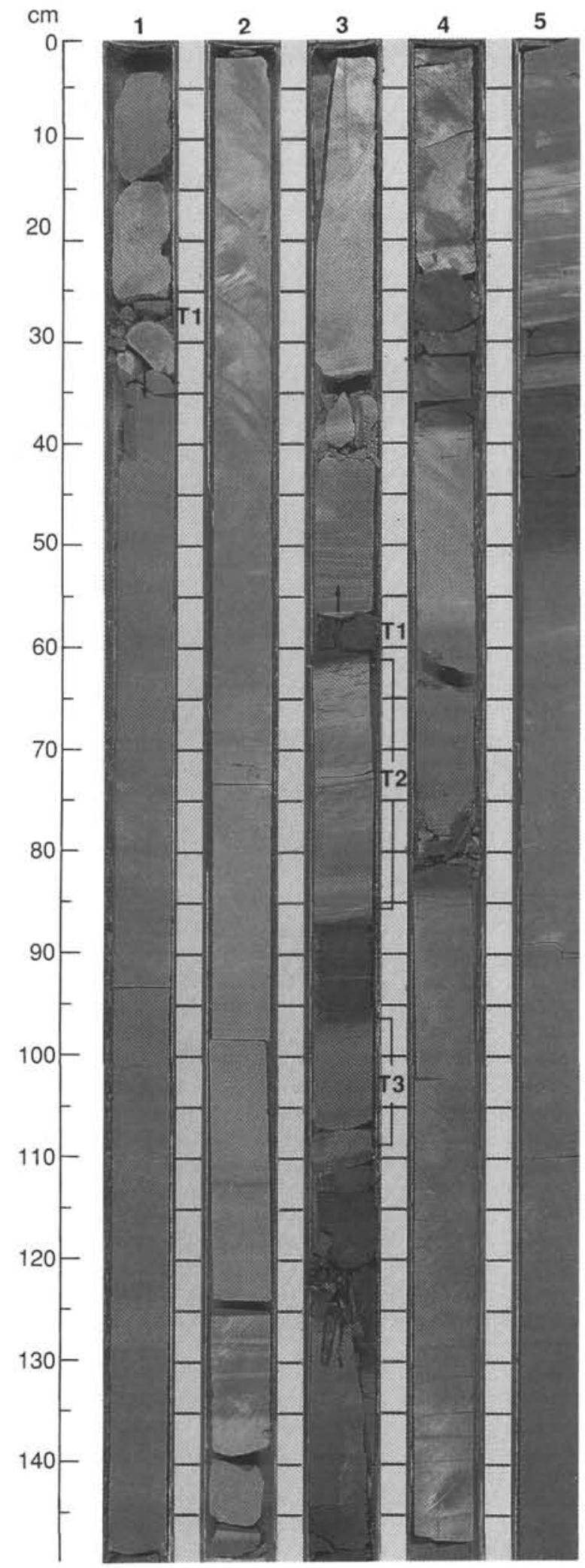

Figure 15. Aptian sediments in Sections 123-765C-38R-1 through -38R-5. Turbidites are lighter colored than background noncalcareous claystone. Like the Valanginian-Hauterivian turbidites, Aptian turbidites range from thick and sandy $\left(T_{1}\right.$, Sections 1-3) to thin and fine-grained $\left(T_{2}\right.$ and $T_{3}$, Section 3$)$; background sediment is relatively less abundant than in the older sediments (cf. Fig. 3). 
even less discrete illite (Compton and Locker, this volume; Compton, pers. comm., 1990); carbonate content is more variable and somewhat higher than in the older turbidites and ranges between $10 \%$ and $55 \%$ (Table 2). Nannofossil assemblages are diverse, moderately to well preserved, and do not contain reworked older components (Dumoulin and Bown, this volume). Silty/sandy laminae contain radiolarians, calcispheres, and minor amounts of quartz, glauconite, small pelagic foraminifers, inoceramid prisms, calcareous lithic clasts, opaque grains, and plagioclase.

\section{Depositional Models}

Stow and Piper's model (1984) aptly describes these sequences (Fig. 7). Compared to the Valanginian-Hauterivian fine-grained turbidites, the Aptian turbidites are thicker and more than $60 \%$ show the complete E1 to E/F structural sequence. Base-cut-out turbidites (lacking the E1 laminated division) range from 2 to 19 $\mathrm{cm}$ thick and average $7.5 \mathrm{~cm}$; complete $\mathrm{E} 1$ to $\mathrm{E} / \mathrm{F}$ turbidites are 3 to $53 \mathrm{~cm}$ thick but average $17 \mathrm{~cm}$.

\section{Coarse-Grained Turbidites}

\section{Megascopic Features}

These turbidites have a fine-grained (claystone) upper division (essentially identical in composition and structures to the finegrained turbidites described above) that grades downward into poorly sorted, fine-grained (rarely, medium-grained) sandstone. Individual turbidites range from $10 \mathrm{~cm}$ to more than $4 \mathrm{~m}$ thick $(60 \%$ are at least $50 \mathrm{~cm}$ ) and are generally $15 \%$ to $50 \%$ sandstone. Bases are sharp and some clearly have been scoured. As in the Valanginian-Hauterivian sandy turbidites, B division plane parallel lamination is the dominant structure; $\mathrm{C}$ division cross-laminae are thin and commonly missing (Plate 3, Figs. 2, 3, and 4).

Several distinctive black to dark gray turbidites with sandy bases occur in Cores 123-765C-34R and -35R. C division convolute lamination is particularly well developed in these turbidites.

Table 2. Carbonate content of Aptian turbidites and intercalated background sediments at Site 765 .

\begin{tabular}{|c|c|c|c|}
\hline Sample & $\% \mathrm{CaCO}_{3}$ & Sample & $\% \mathrm{CaCO}_{3}$ \\
\hline \multicolumn{4}{|c|}{$\begin{array}{l}\text { NANNOFOSSIL CLAYSTONES (fine-grained turbidites or fine-grained } \\
\text { upper parts of coarse-grained turbidites) }\end{array}$} \\
\hline $123-765 \mathrm{C}-34 \mathrm{R}-3,115 \mathrm{~cm}^{\mathrm{a}}$ & $22 *$ & $39 \mathrm{R}-1,30 \mathrm{~cm}^{\mathrm{c}}$ & 32 \\
\hline $35 \mathrm{R}-1,145 \mathrm{~cm}$ & $19 *$ & $39 \mathrm{R}-1,82 \mathrm{~cm}^{\mathrm{c}}$ & 32 \\
\hline $37 \mathrm{R}-2,143 \mathrm{~cm}$ & $18^{*}$ & $39 \mathrm{R}-2,52 \mathrm{~cm}^{\mathrm{c}}$ & 34 \\
\hline $37 \mathrm{R}-3,40 \mathrm{~cm}$ & $35^{*}$ & $39 \mathrm{R}-2,108 \mathrm{~cm}^{\mathrm{c}}$ & 27 \\
\hline $37 \mathrm{R}-3,110 \mathrm{~cm}^{\mathrm{b}}$ & $55^{*}$ & $40 \mathrm{R}-3,145 \mathrm{~cm}^{\mathrm{d}}$ & $10^{*}$ \\
\hline $37 \mathrm{R}-3,140 \mathrm{~cm}^{\mathrm{b}}$ & $52 *$ & & \\
\hline \multicolumn{4}{|c|}{ CALCAREOUS SANDSTONES (lower parts of coarse-grained turbidites) } \\
\hline $34 \mathrm{R}-4,66 \mathrm{~cm}^{\text {a\# }}$ & 17 & $39 \mathrm{R}-3,0 \mathrm{~cm}^{\mathrm{c}}$ & $26^{*}$ \\
\hline $37 \mathrm{R}-4,53 \mathrm{~cm}$ b\#\# & 40 & $40 \mathrm{R}-4,54 \mathrm{~cm}^{\mathrm{d}}$ & 40 \\
\hline $38 \mathrm{R}-5,21 \mathrm{~cm}$ & 22 & & \\
\hline \multicolumn{4}{|l|}{ BLACK TURBIDITES } \\
\hline $34 \mathrm{R}-2,0 \mathrm{~cm}$ & $4 *$ & $35 \mathrm{R}-3,86 \mathrm{~cm}^{\mathrm{e}}$ & $5^{*}$ \\
\hline $35 \mathrm{R}-3,55 \mathrm{~cm}^{\mathrm{e}}$ & $7 *$ & $35 \mathrm{R}, \mathrm{CC}$ & $11^{*}$ \\
\hline \multicolumn{4}{|l|}{ BACKGROUND CLAYSTONES } \\
\hline $35 \mathrm{R}-3,24 \mathrm{~cm}$ & $0^{*}$ & $39 \mathrm{R}-3,101 \mathrm{~cm}$ & $1^{*}$ \\
\hline $36 \mathrm{R}-5,145 \mathrm{~cm}$ & $1 *$ & $40 \mathrm{R}-3,104 \mathrm{~cm}$ & $1^{*}$ \\
\hline
\end{tabular}

* from Ludden, Gradstein, et al., 1990.

$\mathrm{a}, \mathrm{b}, \mathrm{c}, \mathrm{d}$, and $\mathrm{e}$ samples taken from a single turbidite; $\mathrm{d}$ turbidite is rich in authigenic carbonate.

\# sample is rich in radiolarians.

\#\# sample is rich in calcareous clasts.

\section{Composition}

A mixed composition of clayey lithic clasts and calcareous and siliceous bioclasts characterizes the sandy parts of the Aptian turbidites (Fig. 16, Plate 4). Calcareous fossils are pelagic foraminifers, dominantly primitive hedbergellids (Ludden, Gradstein, et al., 1990), and lesser benthic foraminifers, inoceramid prisms, and calcispheres. Only a few of the inoceramid prisms observed are pitted (bored?). Siliceous bioclasts are mainly radiolarians. Lithic clasts consist of claystone and marlstone; the marly clasts contain nannofossils and calcispheres. Nannofossils also fill many foraminifer and radiolarian chambers.

Carbonate content analyses of several sandy turbidites yield values of $17 \%$ to $40 \%$ (Table 2), slightly lower than determinations for the fine-grained Aptian turbidites, but higher than results from Valanginian-Hauterivian sandy turbidites. SEM and thin section observations suggest that marly clasts in the Aptian sandstones contain a higher ratio of nannofossils to clay than do marly clasts in the older sandstones. Relative proportions of clast types are similar to those in the older turbidites, but show distinct changes upward within the sequence. For example, turbidites in the lower cores (123-765C-37R through -40R) are dominated by marly lithic clasts $(30 \%-40 \%)$ and pelagic foraminifers $(20 \%-$ $30 \%$ ) and contain $10 \%$ to $15 \%$ radiolarians. Turbidites in the upper cores contain more radiolarians (generally at least $40 \%$ ) and $10 \%$ to $20 \%$ each of marly clasts and foraminifers. Claystone clasts are a subordinate constituent, typically $5 \%$ to $15 \%$, of most turbidites throughout the sequence. Marked small-scale compositional layering characterizes all turbidites and is discussed below.

Subordinate components of the Aptian sandstones include quartz (angular grains, generally $5 \%$ or less), glauconite, phosphatic debris, opaque grains, white mica, and rare plagioclase, microcline, tourmaline, and biotite.

The dark-colored turbidites that occur intercalated with greenish-gray turbidites in Cores $123-765 \mathrm{C}-34 \mathrm{R}$ and $-35 \mathrm{R}$ have a distinctive composition. They contain notably less carbonate (only $4 \%-11 \%$; Table 2 ), more organic matter (total organic carbon is $0.59 \%-1.08 \%$, vs. less than $0.1 \%$ for other Aptian turbidites at Site 765), and are enriched in radiolarians and clay clasts. They also contain abundant, well-preserved palynomorph assemblages, including a relatively high percentage of pollen grains to dinoflagellates (Ludden, Gradstein, et al., 1990).

\section{Compositional Layering}

Compositional layering in the Aptian sandy turbidites, in general, is similar to that seen in the Valanginian-Hauterivian sequences and is expressed on several scales. The coarsest feature is a greater abundance of claystone clasts (relative to calcareous lithic clasts) noted toward the base of several turbidites; for example, the claystone/marlstone clast ratio in the thick turbidite in Section 123-765C-40R-4 shifts from about $1: 1$ to $8: 1$ within the basal $10 \mathrm{~cm}$.

Two sorts of compositional segregation make up B division parallel laminae in these turbidites. The first type of laminae are thin $(0.25-0.5 \mathrm{~mm}$, rarely to $1 \mathrm{~mm})$, distinct concentrations of dense grains notably smaller than the surrounding lithic clasts. Quartz grains and/or calcispheres are the primary components of these laminae; other constituents include opaques, inoceramid or other mollusk fragments, glauconite, phosphatic detritus, and small foraminifers. The second sort of lamination is thicker $(0.5-5$ $\mathrm{mm}$ ) and more diffuse, and concentrates foraminifers vs. lithic clasts or clay clasts vs. calcareous clasts. Discrete laminae enriched in radiolarians were not observed in any of the Aptian turbidites. 


\section{Depositional Models}

Bouma's model (1962) fits the coarse-grained Aptian turbidites well; like the Valanginian-Hauterivian sandy turbidites, most are base-cut-out $\mathrm{B}(\mathrm{C}) \mathrm{DE}$ sequences with the $\mathrm{C}$ division thin, poorly developed, or absent. B division parallel lamination is the dominant structure and in the thickest turbidites may be distinctly visible through intervals 20 to $30 \mathrm{~cm}$ thick. Several Aptian turbidites include the basal A division (graded but structureless); this division was not observed in any of the Valanginian-Hauterivian sequences.

The absence in the Aptian turbidites of relatively thick and widely spaced radiolarian-rich laminae like those in the older turbidites is puzzling, since general grain sizes and types in the two turbidite intervals appear similar. Absolute abundance of radiolarians within the turbidite may control whether distinct radiolarian-rich laminae are formed; Aptian turbidites in Cores $123-765 C-34 R$ and $-35 R$ may be too rich in radiolarians for well-defined laminae to develop. Turbidites in the lower Aptian cores contain fewer radiolarians, but also contain pelagic foraminifers not present in the Valanginian-Hauterivian sediments. In at least some of the samples examined, foraminifer-rich laminae also are relatively rich in radiolarians, suggesting that the two grain types may be rough hydraulic equivalents. Perhaps the abundance of foraminifers in these sediments has diluted or masked any tendency to segregate radiolarians from lithic clasts.

Carbonate content profiles through individual Aptian turbidites (Table 2) show slightly more variability than was observed in the Valanginian-Hauterivian turbidites, but no clear-cut trends can be discerned. As in the older sediments, most Aptian turbidites become more calcareous upward, but turbidites rich in authigenic manganese carbonate show the opposite pattern.

\section{Diagenesis}

Because the Aptian turbidites are similar in composition and texture to the Valanginian-Hauterivian turbidites, effects of diagenesis in the two sequences also are similar, and differences between the two are mainly attributable to the greater depth of burial of the older sediments. Manganese carbonate and barite occur but are less abundant in the Aptian turbidites, and radiolarian tests are largely altered to opal-CT (Plate 5).

Trace amounts of authigenic carbonate, as rhombs 3 to $15 \mu \mathrm{m}$, rarely to $45 \mu \mathrm{m}$, occur disseminated in several of the Aptian turbidites and are scattered in the intercalated background claystones. Authigenic carbonate is abundant $(10 \%-40 \%)$ only in the lowest turbidite (Sections 123-765C-40R-3 and -40R-4), where rhombs fill radiolarian and foraminifer tests, replace marly lithic clasts, and occur more sparsely within clay clasts and clayey matrix (Plate 5, Fig. 1). Shipboard XRD analysis of a sample from this turbidite indicated that dolomite was the major constituent (Ludden, Gradstein, et al., 1990). However, EDS analyses were performed on several samples from this turbidite; all carbonate rhombs analyzed were manganese-rich, did not contain magnesium, and probably are rhodochrosite. Nannofossils in this interval are poorly preserved; growth of manganese carbonate at the expense of calcium carbonate, as proposed above for some Valanginian-Hauterivian sediments, may have affected this turbidite.

Barite occurrences in the Aptian turbidites are similar to, though somewhat less abundant than, those described above in the Valanginian-Hauterivian turbidites. Large euhedral crystals grow within radiolarian tests and are disseminated in coarse-grained turbidites, particularly those rich in carbonate clasts.

In contrast to the Valanginian-Hauterivian turbidites, which contain many radiolarian tests recrystallized to microcrystalline quartz, the Aptian turbidites include abundant radiolarian tests made of opal-CT. Discrete opal-CT lepispheres 2 to $6 \mu \mathrm{m}$ in diameter replace radiolarian skeletal elements and fill both radiolarians and foraminifer tests (Fig. 16, Plate 5). Other radiolarians contain sheaves of chalcedonic cement. Radiolarian tests containing chalcedony and others filled with opal-CT may occur together in a single turbidite, or within a single laminae in a turbidite. Chalcedony is particularly abundant in the more radiolarian-rich turbidites in the upper half of the unit. Some foraminifer tests are also filled with chalcedony. Several samples were noted in which
A

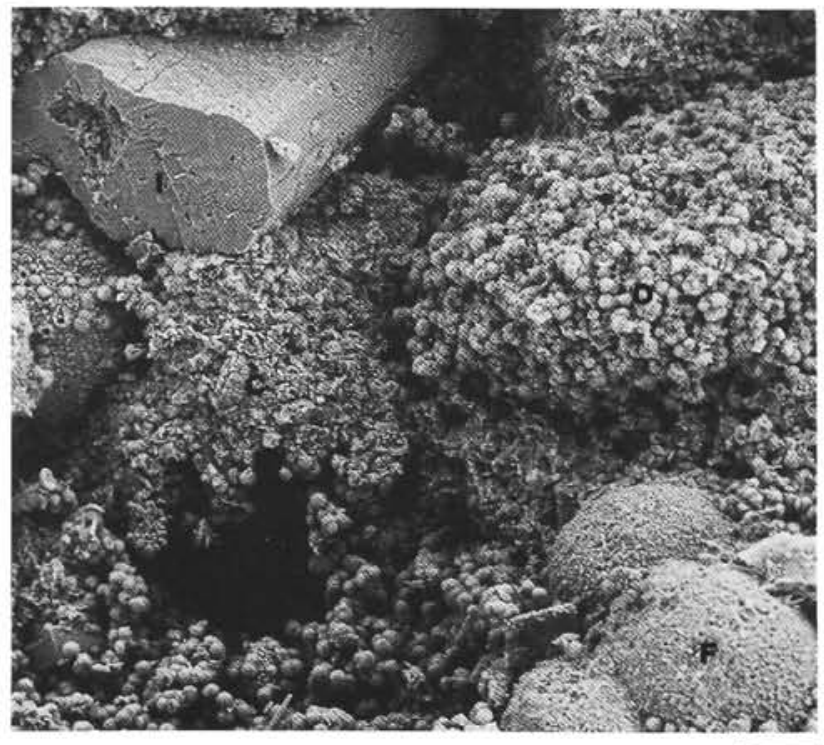

B

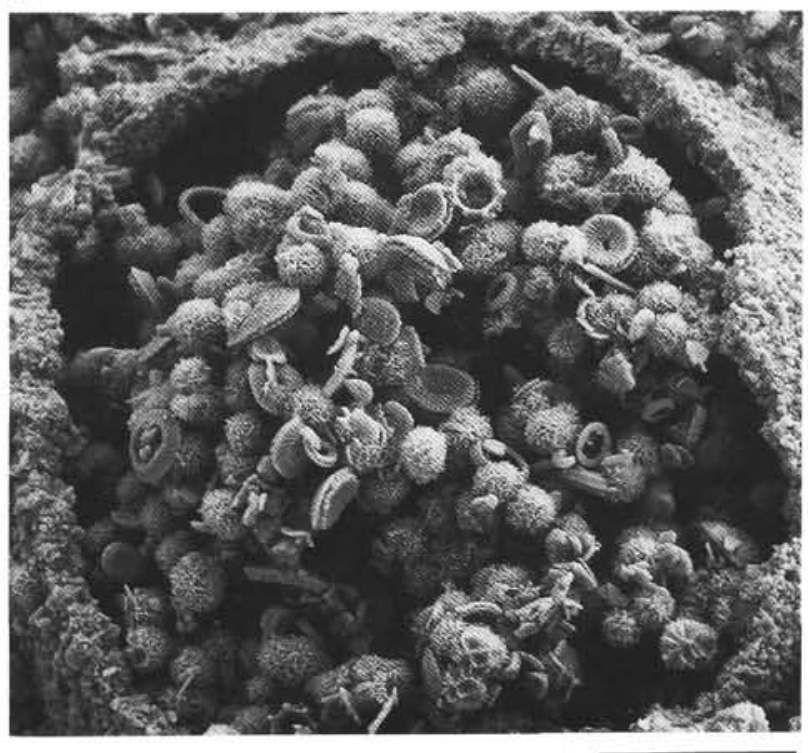

Figure 16. SEM micrographs of Aptian coarse-grained turbidites; scale bars equal $20 \mu \mathrm{m}$. A. Inoceramid prism (I), planktonic foraminifer (F), nannofossil-bearing claystone clast (C), and mass of opal-CT lepispheres (O); Sample 123-765C-37R-1,119-123 cm. B. Foraminifer test filled with nannofossils (mainly Watznaueria fossacincta) and opal lepispheres; Sample 123-765C-37R-1, 119-123 cm. 
radiolarians in noncalcareous background claystone contained opal-CT, whereas those in adjacent calcareous turbidites were chalcedonic. This observation agrees with the experimental results of Kastner et al. (1977), which indicated that the transformation from opal-A to quartz is greatly enhanced in calcareous sediments relative to clay-rich sediments.

\section{ORGANIZATION AND DERIVATION OF TURBIDITE SEQUENCES}

\section{Facies Patterns}

Vertical facies patterns within turbidite sequences have been used by many authors to recognize specific depositional subenvironments, such as slope apron, submarine fan, or basin plain (e.g., Nelson and Nilsen, 1984; Stow and Piper, 1984). Although overall core recovery for both the Valanginian-Hauterivian and Aptian turbidite sequences at Site $123-765 \mathrm{C}$ was good (70\% or better), neither sequence shows progressive vertical changes in turbidite thickness and/or grain-size (Fig. 17). Rather, both sequences consist dominantly of thin- to medium-bedded (20 cm or less), fine-grained (clay- to fine sand-sized) turbidites, punctuated by rare thick-bedded turbidites that contain medium- to coarsegrained sand. This depositional pattern is characteristic of modern abyssal plains (Pilkey, 1987).

Although clear-cut gradational changes in bed thickness or grain-size were not observed in either of the Lower Cretaceous turbidite sequences, the Valanginian-Hauterivian sequence has more thick-bedded and coarse-grained turbidites in its lower part. The number of thick-bedded, coarse-grained turbidites remains relatively constant throughout the Aptian sequence, but more thin-bedded, fine-grained turbidites occur in its lower half. The Aptian turbidite sequence as a whole is thicker-bedded and coarser-grained (more turbidites contain sand) than the Valanginian-Hauterivian sequence, and it contains less intercalated background claystone.

\section{Sediment Sources}

Lower Cretaceous turbidites at Site 765 are distinguished by their hybrid "smarl" composition. Although relative proportions of components vary from turbidite to turbidite, all turbidites studied, both fine- and coarse-grained, contain a mixture of clay and calcareous and siliceous biogenic grains. The ValanginianHauterivian turbidites are somewhat less variable and less calcareous than the Aptian turbidites $\left(8 \%-33 \% \mathrm{CaCO}_{3}\right.$, average $20 \%$, vs. $4 \%-55 \% \mathrm{CaCO}_{3}$, average $25 \%$ ) and do not contain planktonic calcareous foraminifers. Although planktonic foraminifers evolved during the Jurassic, they were not abundant or diverse until the late Early Cretaceous (Boersma, 1978).

Site 765 Lower Cretaceous turbidites also are characterized by the strictly pelagic or deep-water benthic affinities of their contained biogenic grains. Nannofossils, planktonic foraminifers, calcispheres, and radiolarians are the most abundant biogenic components; rarer benthic organisms (mainly calcareous and agglutinated foraminifers) chiefly indicate a bathyal or abyssal origin (Ludden, Gradstein, et al., 1990; Kaminski, Gradstein, et al., this volume). Inoceramid prisms are locally abundant; inoceramids are most common in upper bathyal-to-neritic environments, but have been noted, apparently in situ, to abyssal depths, and their shell material is notably resistant to destruction and dissolution (see Dumoulin and Bown, this volume). No fossils diagnostic of benthic shallow-water depositional environments, particularly forms such as red or green algae that have been confined to the photic zone were recovered from these sediments. However, most of the calcareous biogenic grains are well-preserved and exhibit little dissolution; the degree of preservation demonstrates original deposition above the lysocline (Dumoulin and Bown, this volume). The biogenic grains within these turbidites thus denote a relatively deep-water provenance, such as the continental slope or rise, which lay above the CCD but below the photic zone.
VALANGINIAN-HAUTERIVIAN TURBIDITES
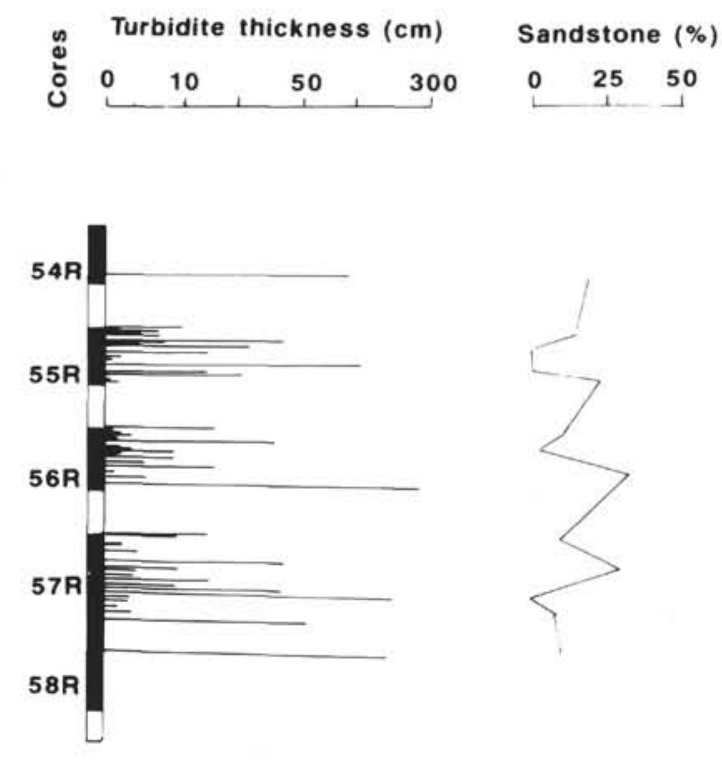

APTIAN TURBIDITES

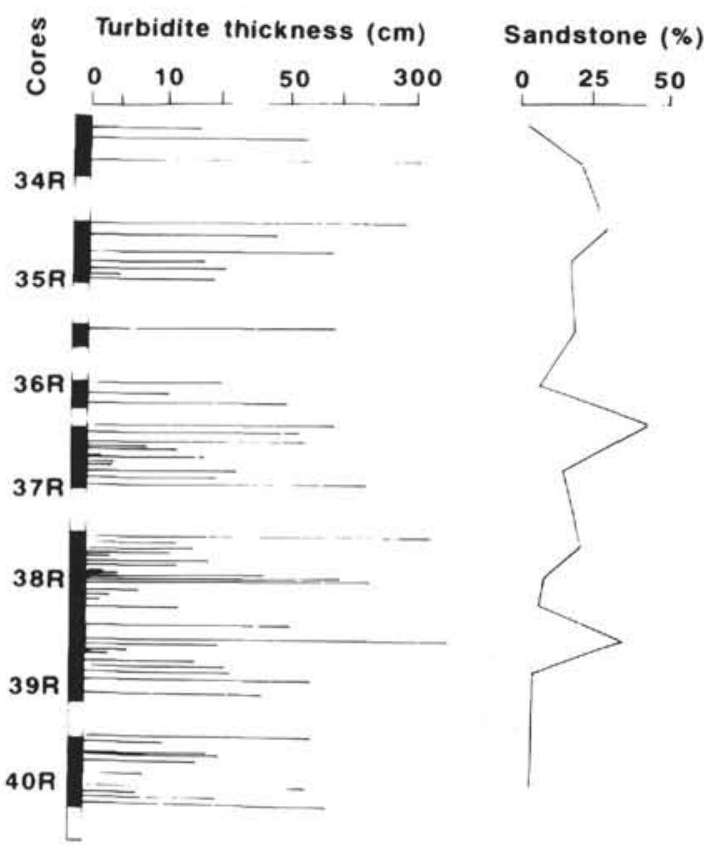

Figure 17. Turbidite bed thicknesses and sandstone percentages for Lower Cretaceous smarl turbidites (Cores 123-765C-58R through -54R and $-40 \mathrm{R}$ through $-34 \mathrm{R})$. 
Lithic clasts in the coarser-grained turbidites indicate a similar or slightly deeper source, as they consist of nannofossil-bearing claystone like that making up the fine parts of the turbidites, and noncalcareous smectite claystone like that intercalated between the turbidites. The irregular shapes of the lithic clasts indicate that most are intraclasts, locally derived, and eroded and redeposited while still semi-consolidated.

In addition, the biogenic fraction of these turbidites reflects derivation from a nutrient-rich continental margin characterized by upwelling. Proposed paleocirculation models suggest that seasonal upwelling occurred along the northwest Australian margin during the Jurassic, and that year-round upwelling prevailed by the mid-Cretaceous (Parrish and Curtis, 1982). Radiolarian assemblages in turbidites at Site 765 support an upwelling model; they are dominated by nontethyan species having high-latitude attributes and are thought to have been introduced into the Argo Basin by circum-Antarctic currents that upwelled along the Australian margin (Baumgartner, this volume). Certain nannofossil species in the Lower Cretaceous turbidites also indicate derivation from a near-shore environment with high nutrient conditions (Dumoulin and Bown, this volume).

Coarse material definitively derived from the Australian continent itself, rather than from pelagic accumulations along its margins, is rare in the Site 765 Lower Cretaceous turbidites. Sandand silt-sized grains of angular quartz are a minor (never more than $10 \%$, and typically less than $5 \%$ ) but persistent component of the turbidites, and probably came from the continental shelf. Other trace components, such as glauconite and heavy minerals, also suggest a shelf provenance.

Clay in the Lower Cretaceous turbidites is volcanogenic and most likely came from the continental margin to the south and, perhaps, to the northeast. XRD analyses indicate that the clay is dominantly smectitic I/S, rich in iron and magnesium, and probably derived from the breakdown of mafic volcanic rocks (Compton and Locker, this volume). Mafic, intermediate, and acidic volcanics of late Triassic-Early Jurassic age buttress the northern margin of the Exmouth Plateau and have been dredged from Montebello Canyon, southwest of Site 765 (von Rad and Exon, 1983; N. Exon, pers. comm., 1989). Mafic volcanics and volcaniclastics of Middle to Late Jurassic age also outcrop extensively along the continental margin northeast of Site 765, in the vicinity of the Scott Plateau (Hinz et al., 1978; Stagg and Exon, 1981); pyroclastic claystones altered to smectite have been dredged along the flanks of Oates Canyon (von Rad and Exon, 1983). Large submarine canyons cut both the Exmouth and Scott plateaus (Fig. 1) and may have provided conduits for transport of volcaniclastic clays to the abyssal plain (see "Discussion" section, below).

Clays derived from the Australian mainland during Lower Cretaceous time do not match the composition of clays in the Site 765 Lower Cretaceous turbidites. Deposits of the Barrow Delta, which prograded north along the west Australian margin through the Early Cretaceous, are clay-rich and have a continental provenance (Boote and Kirk, 1989); the clay in these sediments is largely kaolinite (von Rad and Exon, 1983). Barrow Group sediments form thick accumulations in sub-basins of the Carnarvon Basin and also occur on the Exmouth Plateau, where they thin sharply from south to north (Haq, von Rad, O'Connell, et al., 1990). Thus, it appears that most terrigenous detritus generated in western Australia during the Early Cretaceous was trapped in marginal basins and did not reach the abyssal plain (Dumoulin and Bown, this volume).

Drill and dredge samples from the northern Exmouth Plateau illustrate the type of pelagic sediment that accumulated along the northwest Australian margin during the Early Cretaceous and that was available for redistribution onto the AAP. A condensed inter- val of Neocomian chalk was drilled at Site 761 on the Wombat Plateau, a subplateau of the Exmouth Plateau located southwest of Site 765 (Haq, von Rad, et al., 1990). Major components of this interval are identical to those in the Valanginian-Hauterivian turbidites: nannofossils, calcispheres, lesser radiolarians, and a number of layers of nearly pure smectite clay interpreted as bentonites (Thurow and von Rad, this volume). Aptian radiolarian chalks have been dredged from the northern Exmouth Plateau (von Rad and Exon, 1983) and are similar in composition to the Aptian turbidites at Site 765 .

Both the Exmouth and Scott plateaus subsided rapidly to bathyal depths during the Early Cretaceous (Haq, von Rad, O'Connell, et al., 1990; Stagg and Exon, 1981); surfaces and outer slopes of these plateaus are likely sources for the AAP Lower Cretaceous turbidites. Pelagic marl is accumulating today on the northern Scott Plateau at rates greater than $60 \mathrm{~m} / \mathrm{m}$.y. (Hinz et al., 1978). However, little sediment is being deposited over much of the central plateau; strong bottom currents scour these regions and remove material to other parts of the plateau and to the Java Trench (Shafik, 1978). The extremely condensed nature of the Site 761 Neocomian sequence might reflect similar processes of current removal and redeposition from the Exmouth Plateau to the adjacent continental slope and abyssal plain. Pelagic marls accumulating on the outer slopes of these plateaus - along the continental slope and rise-would also be displaced onto the abyssal plain. Rapidly deposited pelagic sediment is unstable (Stow, 1984; Buchbinder et al., 1988), and slopes along the Exmouth and Scott plateaus are steep-10 $10^{\circ}$ to $17^{\circ}$ (Falvey and Veevers, 1974).

Although the Valanginian-Hauterivian and Aptian turbidite sequences at Site 765 are similar in composition, certain differences do exist and reflect changes in both provenance and paleoceanographic conditions. The Aptian turbidites contain more total palynomorphs, and a higher percentage of pollen relative to dinoflagellates (Helby and McMinn, this volume), which suggests that more material derived from the Australian continent is present in the younger turbidites. This in turn may reflect evolution of the submarine canyon system along the northwest Australian margin (see below). The Aptian turbidites are also more calcareous. This change probably reflects the regional shift to more calcareous sedimentation that took place during the middle Cretaceous across the western Australian margin and has been attributed to initiation of thermohaline circulation in the maturing Indian Ocean (Veevers and Johnstone, 1974).

\section{Sedimentation Rates}

The overall sedimentation rate for the Valanginian-Hauterivian turbidite sequence is low, about $5 \mathrm{~m} / \mathrm{m}$.y. (absolute age data from Ludden, Gradstein, et al., 1990). Turbidites constitute just over half of the total sediments recovered in Cores $123-765 \mathrm{C}-54 \mathrm{R}$ through $-58 \mathrm{R}$. Turbidite frequency through the Valanginian-Hauterivian sequence is just under $1 / 100,000 \mathrm{yr}$., within the range of previous estimates for calcareous turbidites (Stow et al., 1985).

Rates for the Aptian turbidites are higher, 15 to $20 \mathrm{~m} / \mathrm{m}$.y. Turbidites make up more than $80 \%$ of sediments in Cores 123 $765 \mathrm{C}-34 \mathrm{R}$ through $-40 \mathrm{R}$. Turbidite frequency is also higher in the younger sequence, more than $1 / 50,000 \mathrm{yr}$. Sediment colors in the two turbidite sequences support the inference of higher sedimentation rates during the Aptian. The older sequence is predominantly reddish-brown, in contrast to the greenish-gray Aptian turbidites; slower sedimentation rates would allow more time for seafloor oxidation of sediments after deposition.

Sedimentation rates for both Lower Cretaceous smarl turbidite sequences at Site 765 are an order of magnitude lower than accumulation rates reported for modern deep-sea fans (Stow et al., 1985). The low sedimentation rates of the AAP turbidites probably reflect both the configuration of the northwest Australian 
continental margin and the nature of the resedimented material. A series of marginal basins has flanked northwest Australia since early Mesozoic time. Most terrigenous detritus eroded from the Australian landmass during the Early Cretaceous was trapped in these basins and thus was not available for dispersal onto the abyssal plain (Dumoulin and Bown, this volume). Material available for dispersal was thus largely pelagic sediments. Sedimentation rates for pelagic oozes are normally less than $30 \mathrm{~m} / \mathrm{m}$.y. (Stow et al., 1985); thus, accumulation rates for resedimented sequences made up of this material should also be low.

\section{DISCUSSION}

Lower Cretaceous sedimentation patterns at Site 765 elucidate the early history of the western Australian margin and have implications for theories of passive margin evolution. In particular, study of these turbidite sequences yields insight into processes and timing of sediment delivery to the Argo Abyssal Plain, and indicates that generation of calcareous pelagic turbidites at Site 765 coincided with eustatic lowstands.

Submarine canyons appear to have formed early in the evolution of the western Australian margin, but their role in sediment dispersal changed with time. Both the Exmouth and Scott Plateaus are cut by large submarine canyons that debouch onto the abyssal plain (Fig. 1). The canyons on the Exmouth Plateau are structurally controlled and follow the axes of major northeast-trending grabens. Swan Canyon, located due south of Site 765, follows the trend of Swan Graben, which formed in the Late Jurassic; sediments are thought to have been removed from the northern margin of this canyon ever since its inception (Exon et al., 1982). Submarine canyons also incise the Scott Plateau, and here too are controlled by Mesozoic structures (Hinz et al., 1978). The northernmost of these, Oates Canyon, is presently inactive and largely filled with sediment; its steep western margin is interpreted as a left-lateral transform fault. Bowes Canyon, farther south, is also fault-bounded and may still be active. All of these canyons could have provided sediment to the Argo Abyssal Plain during the Lower Cretaceous.

Sedimentation patterns at Site 765 , comparison of these patterns to those at DSDP Site 261 to the north (Dumoulin and Bown, this volume), and seismic lines across the Argo Abyssal Plain (Buffler, 1990) all suggest that multiple sources of turbidite generation prevailed in the Early Cretaceous but gave way to a dominantly southern source in the Late Cretaceous. Correlation of sedimentary successions at Sites 765 and 261 indicate that the Lower Cretaceous section is slightly thicker at Site 261 (Dumoulin and Bown, this volume) whereas from Albian time to the present, three to four times as much sediment was deposited at Site 765. Almost all the "excess" sediments at Site 765 are calcareous turbidites; such turbidites are abundant in the Lower Cretaceous section at Site 261 but rare in younger sediments at this site. Seismic stratigraphic units of Cenozoic and Late Cretaceous age thin from south to north across the basin plain, but the basal seismic unit (the Lower Cretaceous sediments) has a relatively uniform thickness across the plain (Buffler, 1990).

This shift in sediment source was accompanied by changes in depositional processes. Vertical facies patterns in the Lower Cretaceous turbidites do not match those suggested for fans, but rather, fit models proposed for basin plain sedimentation. Sedimentation rates, especially during the Valanginian-Hauterivian, are lower than might be expected for a fan (Stow, 1984), and seismic profiles across Site 765 (Buffler, 1990) show no topography within the Lower Cretaceous sediments that is indicative of a buried fan system. Cenozoic turbidite facies patterns at Site 765, however, and seismic profiles through these sediments that reveal gently mounded configurations, are suggestive of fan deposition
(Ludden, Gradstein, et al., 1990). The role of submarine canyons in sediment dispersal also appears to have changed during the mid-Cretaceous. Features such as Swan Canyon may well have distributed sediment to the AAP during the Early Cretaceous, but this sediment was largely fine-grained and contemporaneous. During Late Cretaceous and, especially, Neogene time, in contrast, submarine canyons adjacent to the AAP were being deeply incised; they contributed abundant coarse-grained sediment (conglomeratic debris flows tens of meters thick) and notably older (Permian-Cretaceous) reworked biogenic grains and clasts (Ludden, Gradstein, et al., 1990). These shifts in sedimentation patterns across the Argo Abyssal Plain reflect changes in global sea level and local tectonic factors and are discussed more fully elsewhere (Dumoulin and Bown, this volume).

Lower Cretaceous sedimentation at Site 765 also reflects both eustatic fluctuations and local tectonics. The Lower Cretaceous succession at this site consists of a thin interval of abundant calcareous turbidites overlain by a thick section of largely finegrained noncalcareous claystone and rare sandy gravity flows and then a second interval dominated by calcareous turbidites. Both appearances of calcareous turbidites at Site 765 coincide with times of postulated short-term eustatic lowstands (Haq et al., 1987) in the Valanginian and in the middle and late Aptian (Fig. 18). Siliciclastic turbidites appear to be most commonly generated during lowstands of sea level (e.g., Shanmagum and Moiola, 1982) but calciclastic turbidites seem to be more abundant during highstands (Droxler and Schlager, 1985). Site 765 calcareous turbidites, however, consist primarily of pelagic biogenic grains, not shallow-water carbonate debris. Lowered sea levels correlate

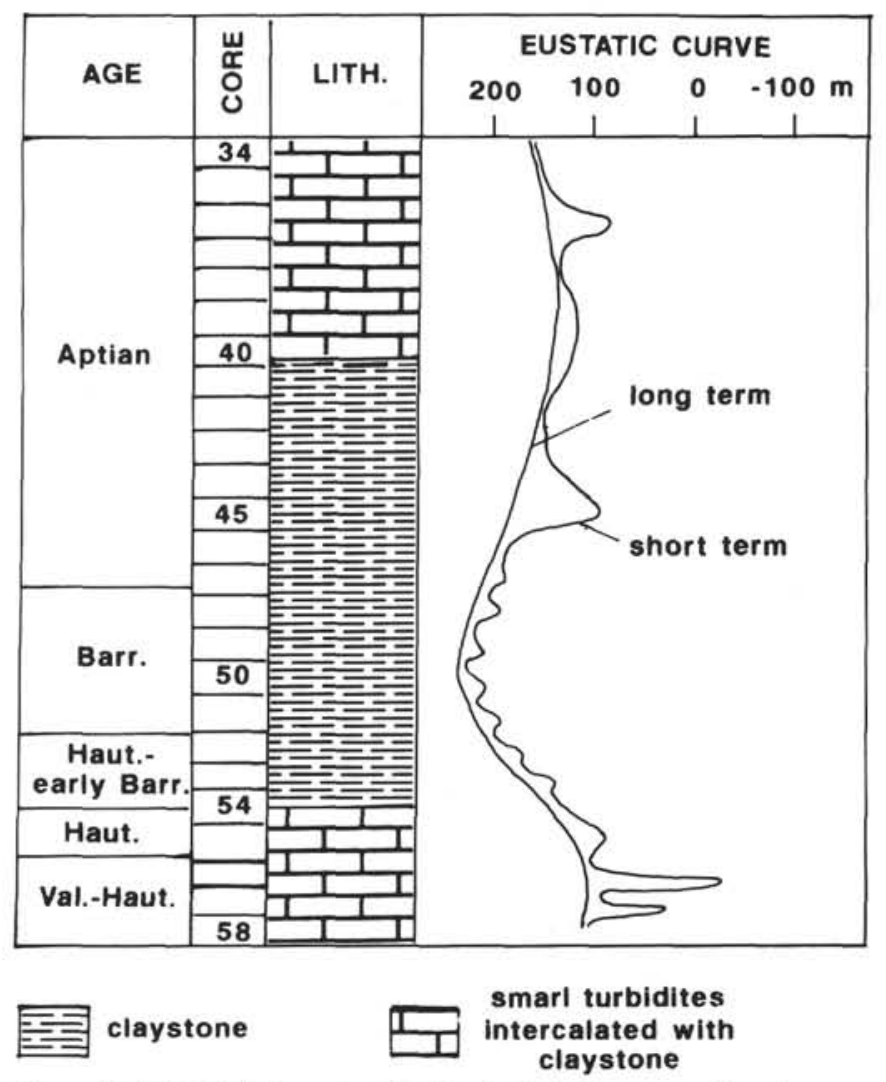

Figure 18. Global shifts in sea level during the Early Cretaceous. Eustatic curve from Haq et al. (1987); 0 = present-day sea level. Curve fitted to chronostratigraphy of Site 765 using magnetostratigraphic and biostratigraphic datums in Kaminski, Baumgartner, et al. (this volume). 
with lowered CCD levels (Kennett, 1982). Thus, during the Early Cretaceous lowstands, more of the continental slope should have been above the CCD and accumulating pelagic carbonate material; the steep lower slopes of the Australian margin would have made this material particularly susceptible to displacement by gravity flows.

Weaver and Kuijpers (1983) and Weaver and Rothwell (1987) examined Quaternary turbidites of the Madeira Abyssal Plain that are similar in composition to the Site 765 calcareous turbidites and concluded that eustatic change, rather than absolute sea level, was the crucial factor in turbidite generation. Madeira turbidites were deposited during times of falling and rising sea level, but not during intervening periods of stable sea level. The biostratigraphic resolution of the Madeira study was much greater than that achieved in investigations of older turbidites, and what appear to be continuous lowstands of sea level in the geologic record may in fact be periods of oscillating sea level (Weaver and Rothwell, 1987). Biostratigraphic control at Site 765 is not precise enough to resolve this argument. However, not all short-term eustatic fluctuations postulated by Haq et al. (1987) for the Early Cretaceous correspond with times of calcareous turbidite accumulation at Site 765. Only those shifts that occurred at times when the long-term global sea level was relatively low appear to have resulted in calcareous turbidite deposition, which suggests that absolute sea level was an important control in generation of these sediments.

Local tectonic factors also influenced Site 765 sedimentation. Much of the Hauterivian-Aptian claystone section between the two intervals of carbonate turbidites appears to consist of finegrained noncalcareous turbidites deposited during a period of high sea level and elevated CCD (Dumoulin and Bown, this volume). Sedimentation rates during accumulation of the upper part of this interval are an order of magnitude higher than those typical of pelagic sedimentation. High sedimentation rates are recorded throughout the eastern Indian Ocean during the early Aptian and appear to reflect increased magmatism and tectonism in Australia at this time (Cook, 1977). However, biostratigraphic data (Ludden, Gradstein, et al., 1990) indicate that the sharpest increase in the sedimentation rate at Site 765 during Cretaceous time occurred at about the level of Core 123-765C-45R. This is roughly coincident (Fig. 18) with the short-term lowstand of sea level proposed for the early Aptian by Haq and others (1987). Thus, both local factors and eustasy may have been important in shaping this part of the Lower Cretaceous section at Site 765.

\section{CONCLUSIONS}

Lower Cretaceous smarl turbidites at Site 765 consist largely of pelagic biogenic grains and smectite clay and clay clasts; most are fine-grained and best described by the Stow and Piper (1984) model for fine-grained biogenic turbidites. The biogenic grains in these turbidites indicate a deep-water source, and the smectite denotes volcanogenic input. The turbidites were likely derived mainly from the continental margin to the south (Exmouth Plateau) with perhaps some input from the margin to the northeast (Scott Plateau). Both these plateaus sank to bathyal depths during the Early Cretaceous and thus would have accumulated pelagic and deep-water benthic biogenic material on their surfaces and outer slopes; Triassic-Jurassic volcanics buttressing the plateaus are a probable source for the smectite. The Lower Cretaceous smarl turbidites do not appear to be part of a submarine fan system, and were generated at times of eustatic low-stands.

\section{ACKNOWLEDGMENTS}

Financial support for this research was provided by a grant from the U.S. Scientific Advisory Committee (USSAC) and is gratefully acknowledged. Richard Emanuel, Eugenio Gonzales, and Jonathan Krupp contributed expert technical assistance, and Robert Garrison, Reinhard Hesse, and Robert Kidd provided helpful reviews of the manuscript. I also express my thanks for the cooperation and helpfulness of my fellow scientists during Leg 123 and the crew of the JOIDES Resolution.

\section{REFERENCES}

Boersma, A., 1978. Foraminifera. In Haq, B. U., and Boersma, A. (Eds.), Introduction to Marine Micropaleontology: New York (Elsevier), 19-77.

Boote, D.R.D., and Kirk, R. B., 1989. Depositional wedge cycles on an evolving plate margin, western and northwestern Australia. AAPG Bull., 73:216-243.

Bouma, A. H., 1962. Sedimentology of Some Flysch Deposits: Amsterdam (Elsevier).

Buchbinder, B., Benjamini, C., Mimran, Y., and Gvirtzman, G., 1988. Mass transport in Eocene pelagic chalk on the northwestern edge of the Arabian platform, Shefela area, Israel. Sedimentology, 35:257274.

Buffler, R. T., 1990. Underway geophysics. In Gradstein, F. M., Ludden, J. N., et al., Proc. ODP, Init. Repts., 123: College Station, TX (Ocean Drilling Program), 13-25.

Cook, P. J., 1977. Mesozoic-Cenozoic sediments of the eastern Indian Ocean. In Heirtzler, J. R., Bolli, H. M., Davies, T. A., Saunders, J. B., and Sclater, J. G. (Eds.), Indian Ocean Geology and Biostratigraphy: Washington (Am. Geophys. Union), 119-150.

Dean, W. E., Stow, D.A.V., Barron, E., and Schallreuter, R., 1984. A revised sediment classification for siliceous-biogenic, calcareousbiogenic and non-biogenic compounds. In Hay, W. W., and Sibuet, J.-C., et al., Init. Repts. DSDP, 75: Washington (U.S. Govt. Printing Office), $12-15$.

Deer, W. A., Howie, R. A., and Zussman, J., 1965. Rock-Forming Minerals (Vol. 5): London (Longman).

Dietrich, R. V., Dutro, J. T., and Foose, R. M. (compilers), 1982. AGI Data Sheets. Am. Geol. Inst.

Droxler, A. W., and Schlager, W., 1985. Glacial versus interglacial sedimentation rates and turbidite frequencies in the Bahamas. Geology, 13:799-802.

Exon, N. F., von Rad, U., and von Stackelberg, U., 1982. The geological development of the passive margins of the Exmouth Plateau off northwest Australia. Mar. Geol., 47:131-152.

Falvey, D. A., and Veevers, J. J., 1974. Physiography of the Exmouth and Scott Plateaus, Western Australia, and adjacent northeast Wharton Basin. Mar. Geol., 17:21-59.

Haq, B. U., Hardenbol, J., and Vail, P. R., 1987. Chronology of fluctuating sea levels since the Triassic. Science, 235:1156-1167.

Haq, B. U., von Rad, U., O'Connell, S., et al., 1990. Proc. ODP, Init. Repts., 122: College Station, TX (Ocean Drilling Program).

Hein, J. R., and Koski, R. A., 1987. Bacterially mediated diagenetic origin for chert-hosted manganese deposits in the Franciscan Complex, California Coast Ranges. Geology, 15:722-726.

Hesse, R., and Chough, S. K., 1980. The Northwest Atlantic Mid-Ocean Channel of the Labrador Sea: II. Deposition of parallel laminated levee-muds from the viscous sublayer of low density turbidity currents. Sedimentology, 27:697-711.

Hinz, K., Beiersdorf, H., Exon, N. F., Roeser, H. A., Stagg, H.M.J., and von Stackelberg, U., 1978. Geoscientific investigations from the Scott Plateau off Northwest Australia to the Java Trench. BMR J. Aust. Geol. Geophys., 3:319-340.

Jakobsen, R., and Postma, D., 1989. Formation and solid solution behavior of Ca-rhodochrosites in marine muds of the Baltic deeps. Geochim. Cosmochim. Acta, 53:2639-2648.

Kastner, M., Keene, J. B., and Gieskes, J. M., 1977. Diagenesis of siliceous oozes. I. Chemical controls on the rate of opal-A to opal-CT transformation-an experimental study. Geochim. Cosmochim. Acta, 41:1041-1059.

Kennett, J. P., 1982. Marine Geology: Englewood Cliffs, New Jersey (Prentice-Hall).

Ludden, J. N., Gradstein, F. M., et al., 1990. Proc. ODP, Init. Repts., 123: College Station, TX (Ocean Drilling Program). 


\section{J. A. DUMOULIN}

Murchey, B. L., Madrid, R. J., and Poole, F. G., 1987. Paleozoic bedded barite associated with chert in western North America. In Hein, J. R. (Ed.), Siliceous Sedimentary Rock-Hosted Ores and Petroleum: New York (Van Nostrand), 269-283.

Nelson, C. H., and Nilsen, T. H., 1984. Modern and ancient deep-sea fan sedimentation. SEPM Short Course, No. 14.

Parrish, J. T., and Curtis, R. L., 1982. Atmospheric circulation, upwelling, and organic-rich rocks in the Mesozoic and Cenozoic eras. Palaeogeogr., Palaeoclimatol., Palaeoecol., 40:31-66.

Pickering, K. T., Hiscott, R. N., and Hein, F. J., 1989. Deep Marine Environments: London (Unwin Hyman).

Pilkey, O. H., 1987. Sedimentology of basin plains. In Weaver, P.P.E., and Thompson, J. (Eds.), Geology and Geochemistry of Abyssal Plains. Geol. Soc. Spec. Publ. London, 31:1-12.

Robertson, A.H.F., and Bliefnick, D. M., 1983. Sedimentology and origin of Lower Cretaceous pelagic carbonates and redeposited clastics, Blake-Bahama Formation, Deep Sea Drilling Project Site 534, western equatorial Atlantic. In Sheridan, R. E., Gradstein, F. M., et al., Init. Repts. DSDP, 76: Washington (U.S. Govt. Printing Office), 795-828.

Schlanger, S. O., and Douglas, R. G., 1974. The pelagic ooze-chalk-limestone transition and its implications for marine stratigraphy. In Hsü, K. J., and Jenkyns, H. C. (Eds.), Pelagic Sediments on Land and Under the Sea. Int. Assoc. Sedimentol. Spec. Publ., 1:117-148.

Scholle, P. A., 1971a. Sedimentology of fine-grained deep-water carbonate turbidites, Monte Antola Flysch (Upper Cretaceous), Northern Apennines, Italy. Geol. Soc. Am. Bull., 82:629-658.

1971b. Diagenesis of deep-water carbonate turbidites, Upper Cretaceous Monte Antola Flysch, Northern Apennines, Italy. J. Sediment. Petrol., 41:233-250.

Shafik, S., 1978. The near-surface sediments of the Scott Plateau and Java Trench: nannofossil assessment and implications. BMR J. Aust. Geol. Geophys., 3:341-345.

Shanmugam, G., and Moiola, R. J., 1982. Eustatic control of turbidites and winnowed turbidites. Geology, 10:231-235.
Stagg, H.M.J., and Exon, N. F., 1981. The geology of the Scott Plateau and Rowley Terrace, off northwestern Australia. Bur. Miner. Resour. Aust. Bull., 213:1-53.

Stow, D.A.V., 1984. Cretaceous to Recent submarine fans in the southeast Angola Basin. In Hay, W. W., and Sibuet, J.-C., et al., Init. Repts. DSDP, 75: Washington (U.S. Govt. Printing Office), 771-784.

Stow, D.A.V., Howell, D. G., and Nelson, C. H., 1985. Sedimentary, tectonic, and sea-level controls. In Bouma, A. H., Normark, W. R., and Barnes, N. E. (Eds.), Submarine Fans and Related Turbidite Systems: New York (Springer-Verlag), 15-22.

Stow, D.A.V., and Piper, D.J.W., 1984. Deep-water fine-grained sediments: facies models. In Stow, D.A.V., and Piper, D.J.W. (Eds.), Fine-Grained Sediments: Deep-Water Processes and Facies: Oxford (Blackwell), 611-645.

van Tassell, J., 1981. Silver Abyssal Plain carbonate turbidite: flow characteristics. J. Geol., 89:317-333.

Veevers, J. J., and Johnstone, M. H., 1974. Comparative stratigraphy and structure of the western Australian margin and the adjacent deep ocean floor. In Veevers, J. J., Heirtzler, J. R., et al., Init. Repts. DSDP, 27: Washington (U.S. Govt. Printing Office), 571-585.

von Rad, U., and Exon, N. F., 1983. Mesozoic-Cenozoic sedimentary and volcanic evolution of the starved passive continental margin off northwest Australia. In Watkins, J. S., Drake, C. L., and Sheridan, R. E. (Eds.), Studies in Continental Margin Geology: AAPG Mem., 34:253-281.

Weaver, P.P.E., and Kuijpers, A., 1983. Climatic control of turbidite deposition on the Madeira Abyssal Plain. Nature, 306:360-363.

Weaver, P.P.E., and Rothwell, R. G., 1987. Sedimentation on the Madeira Abyssal Plain over the last 300, 000 years. In Weaver, P.P.E., and Thompson, J. (Eds.), Geology and Geochemistry of Abyssal Plains. Geol. Soc. Spec. Publ. London, 31:71-86.

Date of initial receipt: 30 May 1990

Date of acceptance: 15 May 1991

Ms 123B-154 


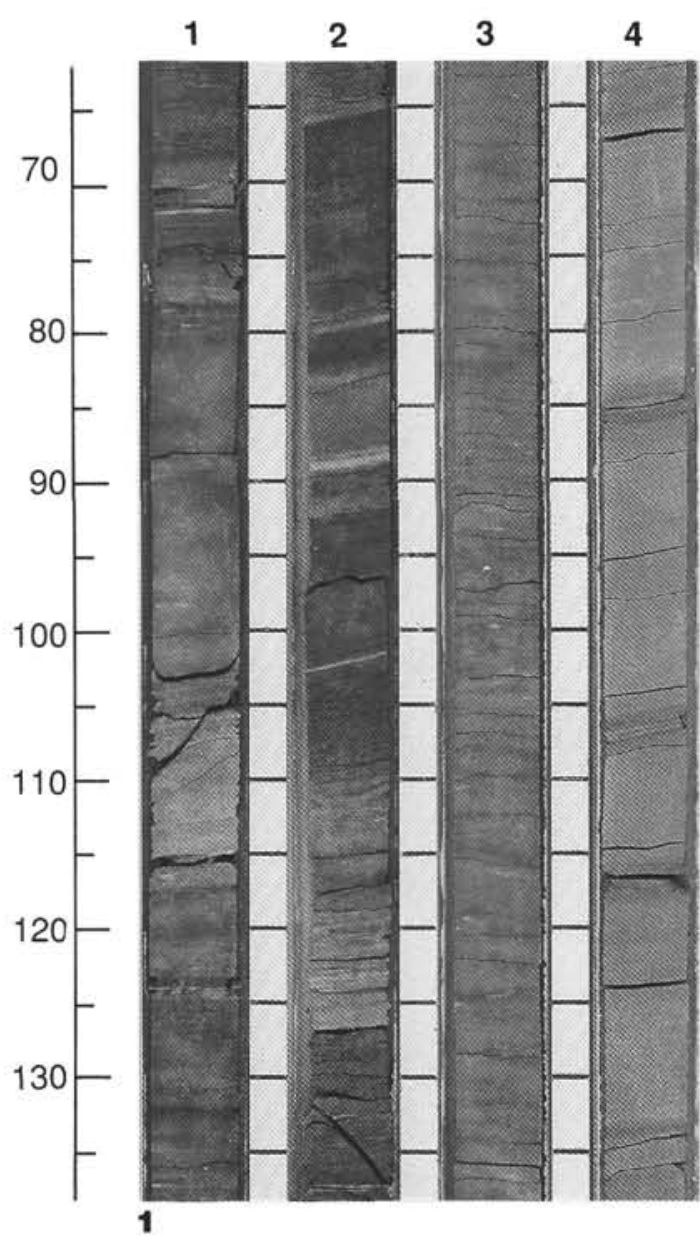

R1

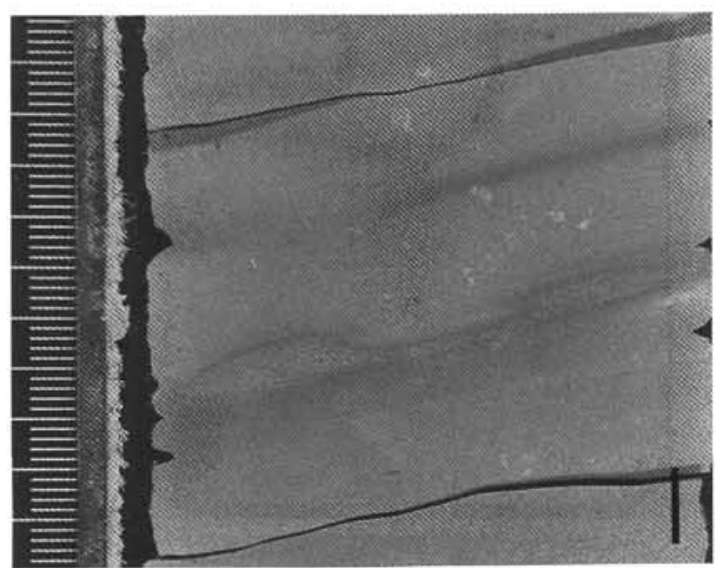

2

R3

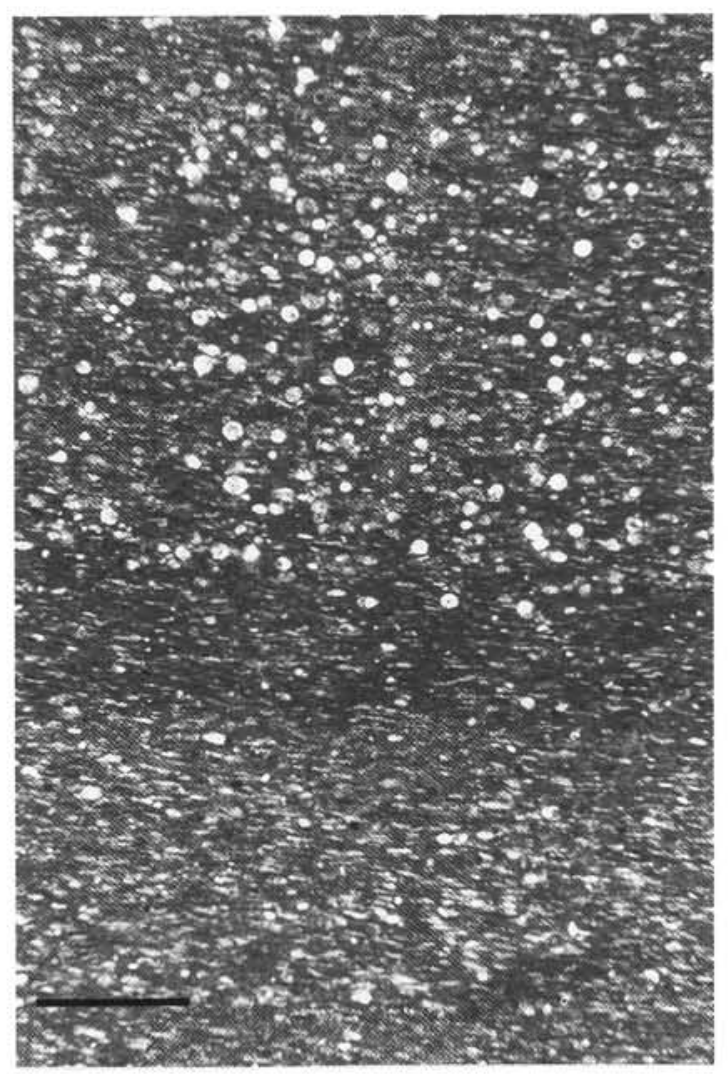

4

Plate 1. Radiolarian-rich horizons in Valanginian-Hauterivian sandy turbidites. 1. Sections 123-765C-56R-1 through $-4,62-138 \mathrm{~cm}$; all of Sections 3 and 4 shown here are part of a single turbidite. Section 4 is largely sandstone, which grades downward from very fine- to medium-grained. White zones with dark sediment above and below are distinct radiolarian-enriched lamina and occur at $68,88,107$, and $117 \mathrm{~cm}$ (R1-R4). 2. Uppermost radiolarian-rich lamina (R1) shown in $\mathbf{A}$ $(65-69 \mathrm{~cm})$; radiolarians average $80 \mu \mathrm{m}$ in diameter. Bar indicates interval shown in Figure D. Scale in millimeters. 3. Coarser-grained radiolarian-rich lamina (R3) lower in A (104-108 cm); radiolarians average $120 \mu \mathrm{m}$. Scale in millimeters. 4. Photomicrograph of radiolarian-rich lamina shown in B; radiolarians are filled with chalcedony. Underlying sediment consists mostly of flattened dark- and light-colored clay-rich lithic clasts. Scale bar is $0.8 \mathrm{~mm}$. 

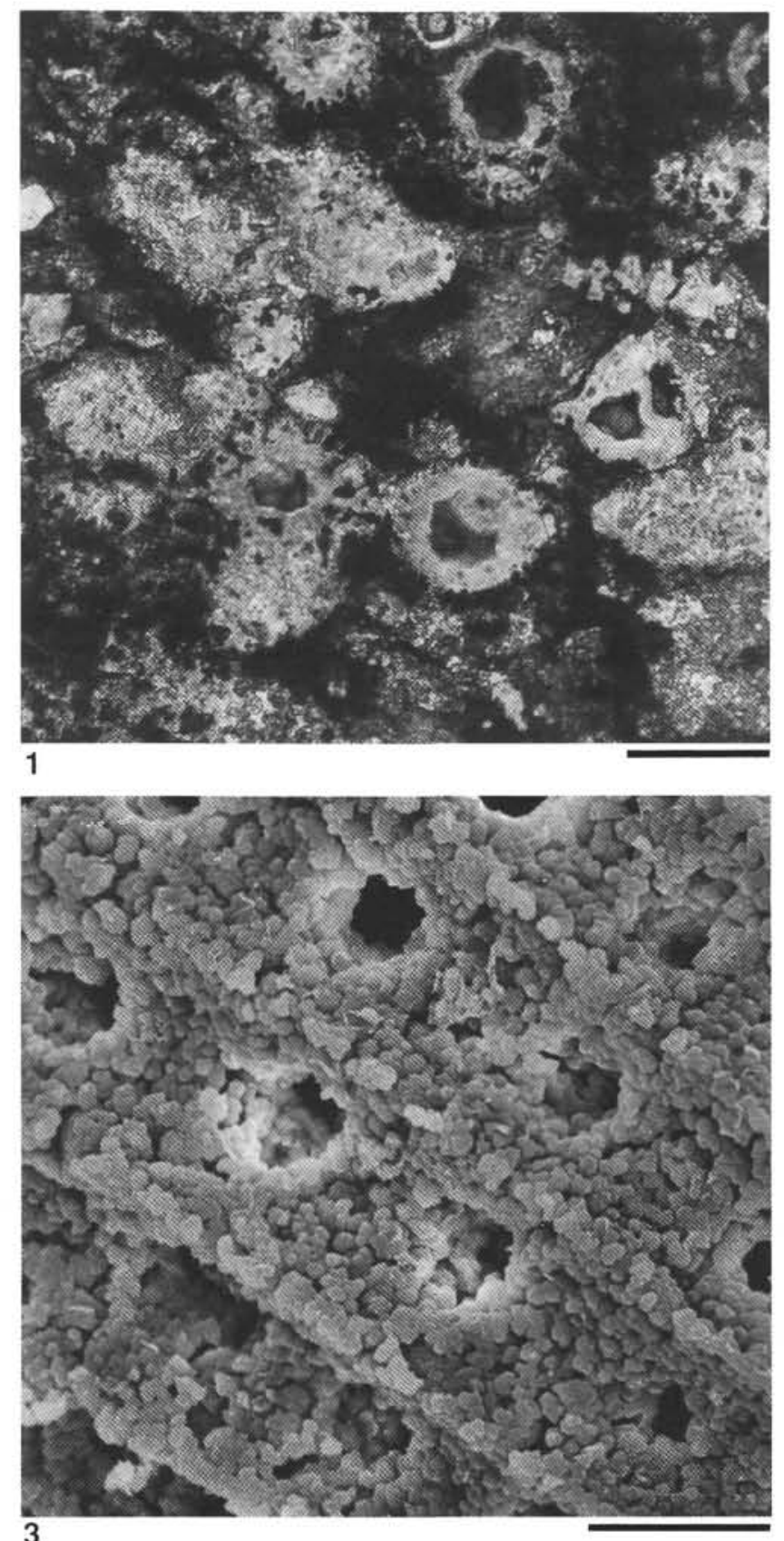

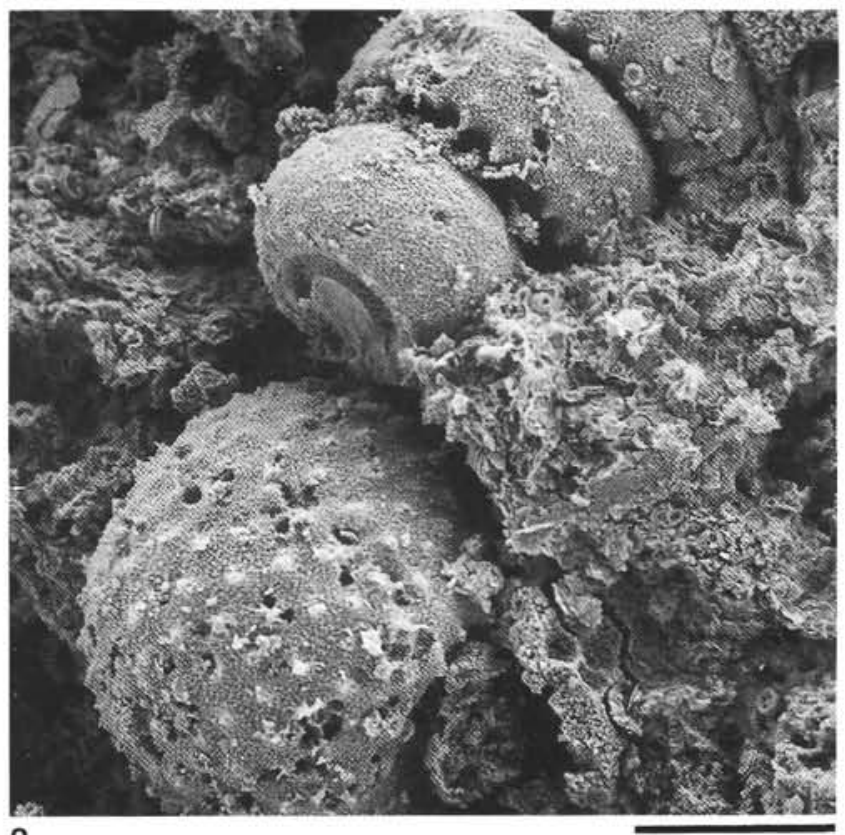

2

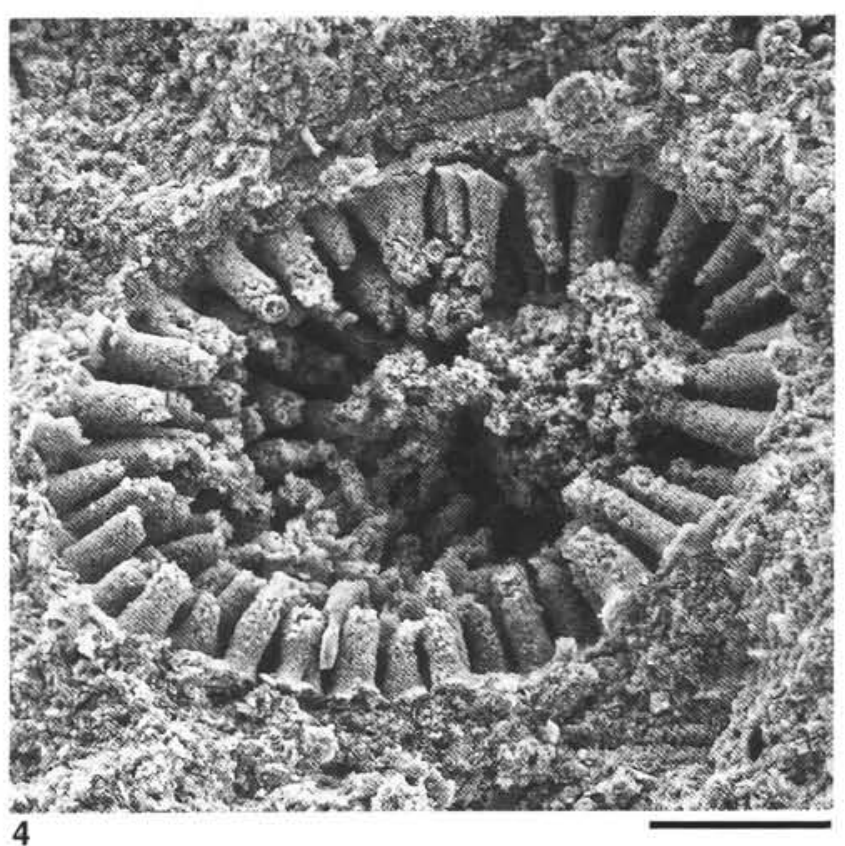

Plate 2. Radiolarians in Valanginian-Hauterivian sediments. 1. Photomicrograph of turbidite containing poorly preserved radiolarians recrystallized to microcrystalline quartz and filled with chalcedony cement. Sample 123-765C-57R-4, 11-15 cm; scale bar is $0.15 \mathrm{~mm} .2$, 3. SEM micrographs of a turbidite containing radiolarians recrystallized to microcrystalline quartz but with preservation of some skeletal structure. Forms in $\mathbf{2}$ are inner molds of tests; $\mathbf{3}$ is the test itself. Sample 123-765C-57R-2, 25-29 cm; scale bar is $40 \mu \mathrm{m}$ in 2, and $8 \mu \mathrm{m}$ in 3. 4. SEM micrograph of radiolarian mold in clay-rich upper part of fine-grained turbidite. Sample 123-765C-57R-4, 72-76 cm; scale bar is $50 \mu \mathrm{m}$. 

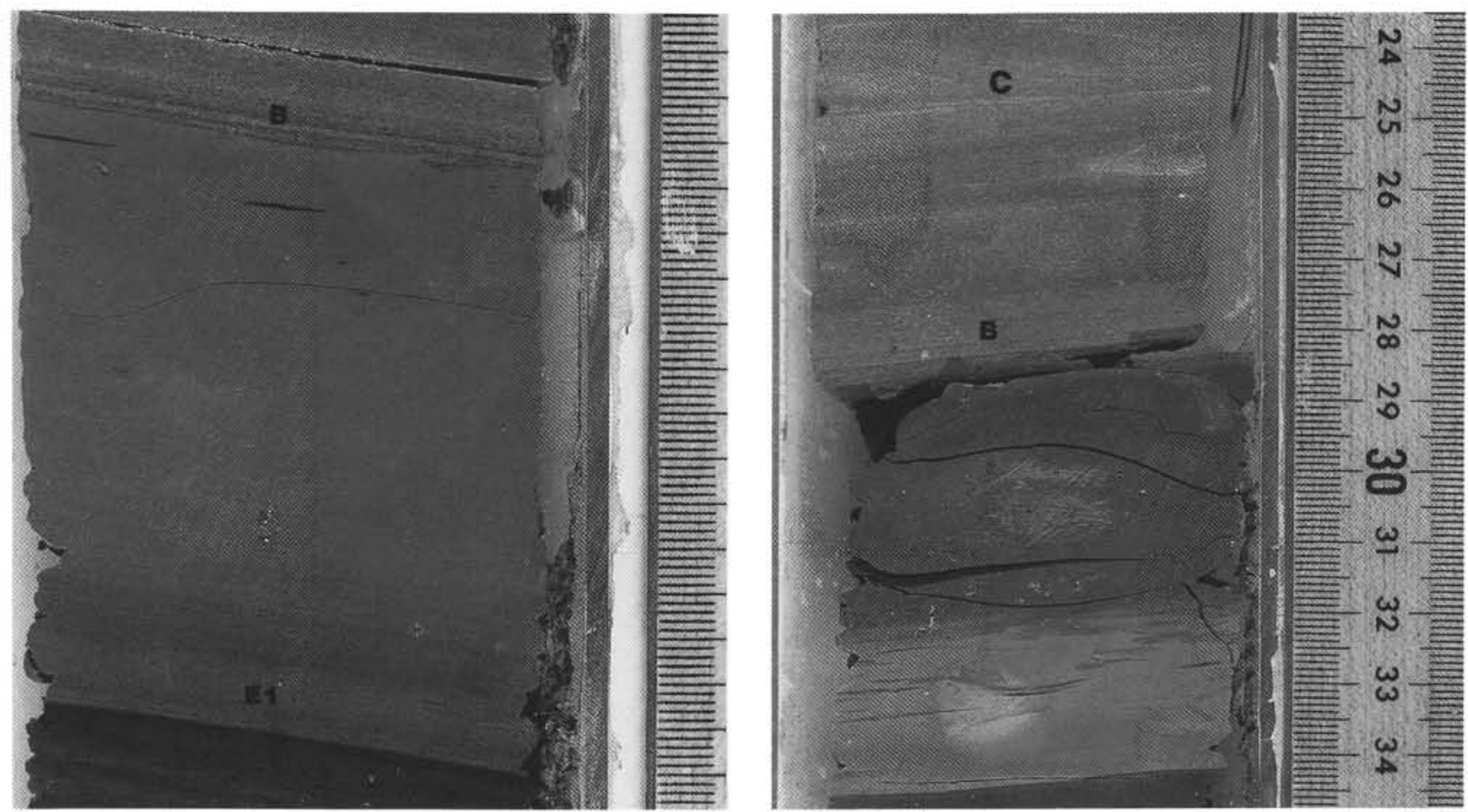

1

2

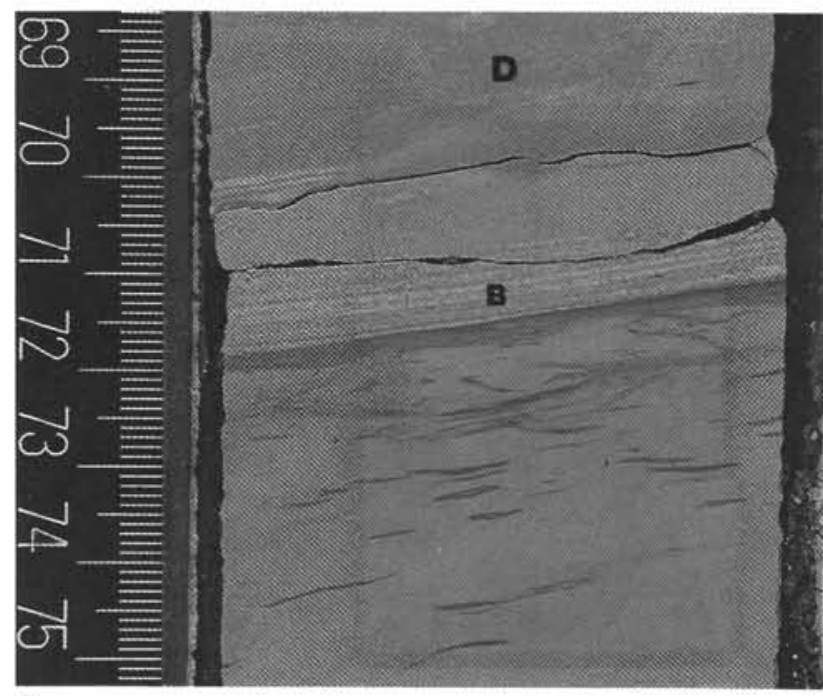

3

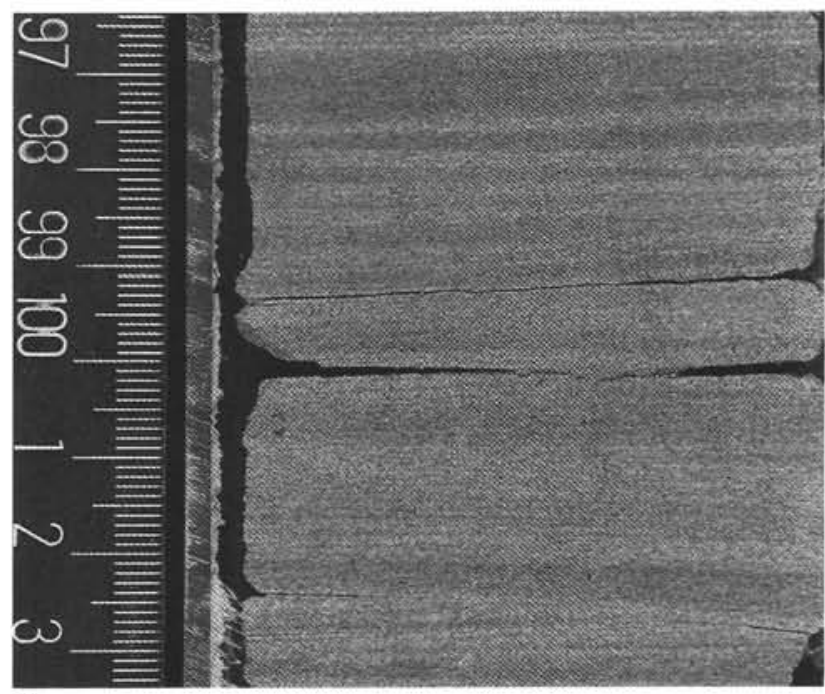

4

Plate 3. Aptian turbidites; white laminae are concentrations of quartz and/or foraminifers. 1. Coarse-grained (sandy) turbidite with fine B division plane laminae at base overlies and truncates fine-grained turbidite with E1 silty laminae at base; Section 123-765C-40R-3, 5-14 cm. 2. Coarse-grained turbidite with B division plane laminae and unusually well-developed $\mathrm{C}$ division cross-laminae above fine-grained base-cut-out turbidite; Section 123-765C-38R-5, 24-35 cm. 3. More typical coarse-grained turbidite with B and D division parallel laminae but with C division cross-laminae absent; Section 123-765C-38R-3, 69-76 cm. 4. Thick interval of B division parallel lamination in coarse-grained turbidite; Section $123-765 \mathrm{C}-35 \mathrm{R}-2,97-103 \mathrm{~cm}$. 

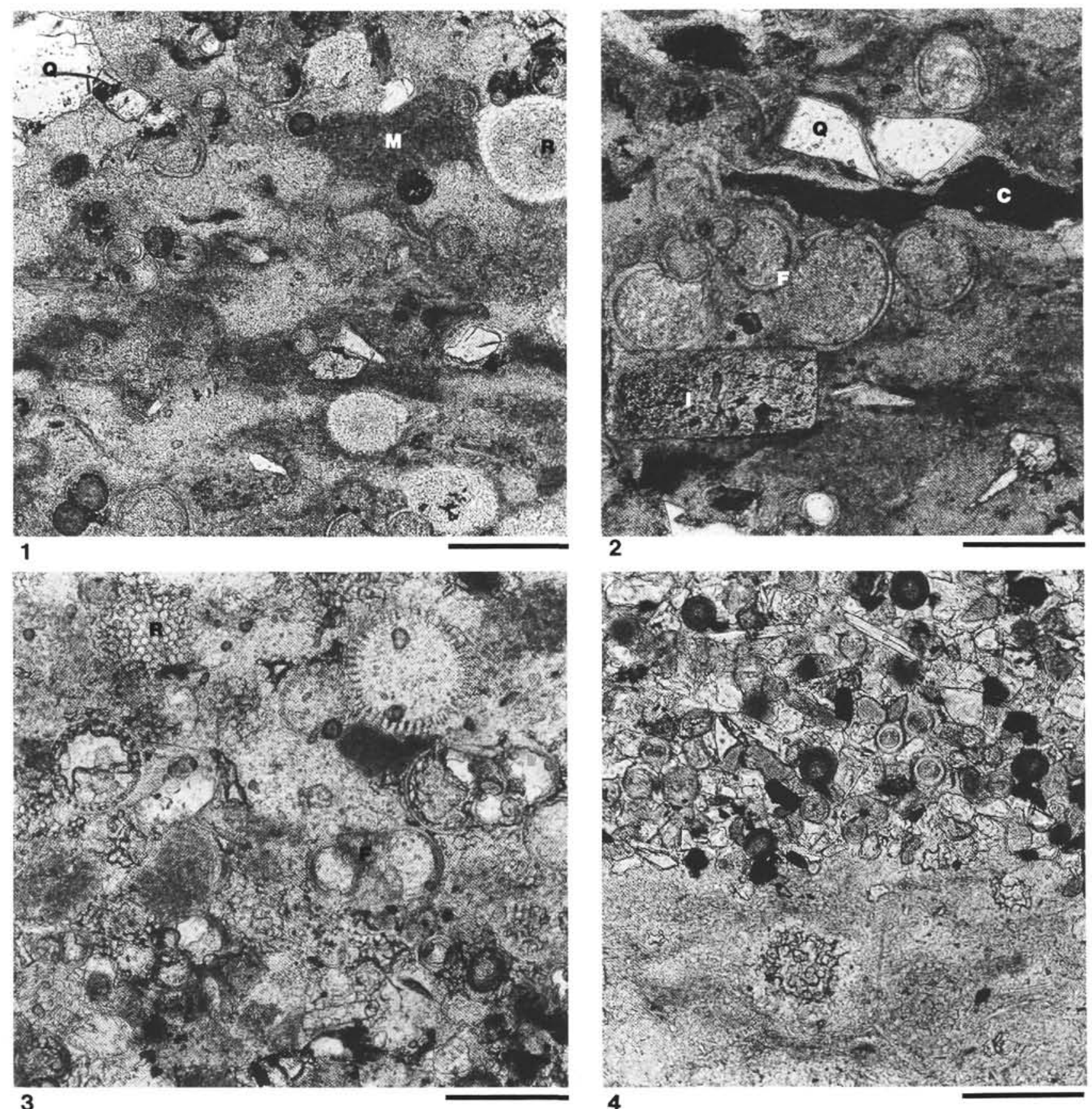

2

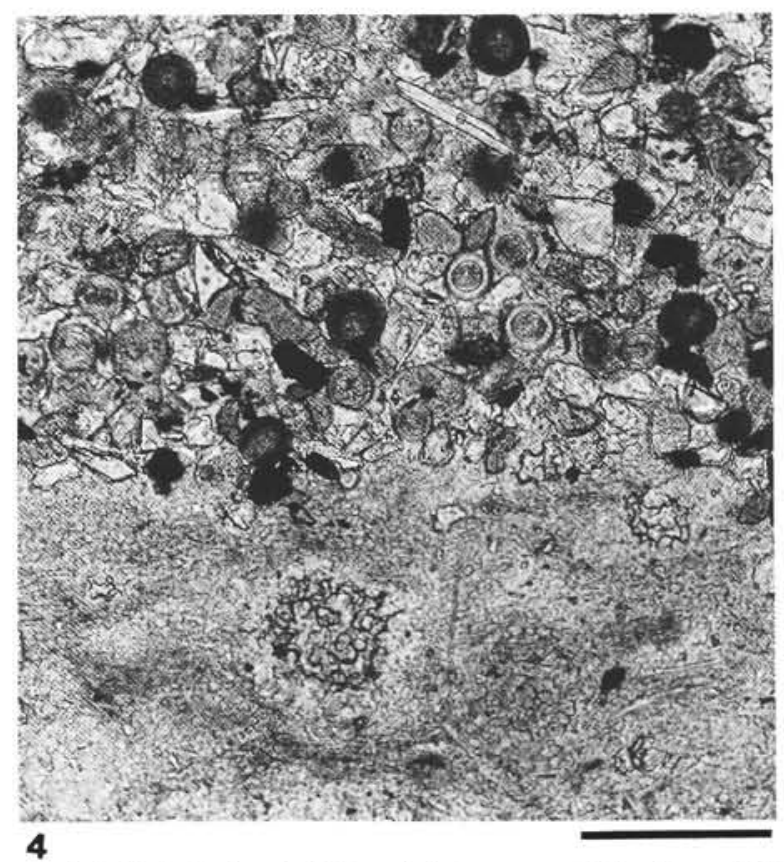

Plate 4. Photomicrographs of Aptian coarse-grained turbidites; scale bars equal $0.15 \mathrm{~mm}$. 1-3. Typical clasts include radiolarians recrystallized to opal-CT but preserving some details of original structure $(\mathrm{R})$, planktonic foraminifers $(\mathrm{F})$, quartz $(\mathrm{Q})$, inoceramid prism with microborings (I), claystone rich in organic matter (C), and nannofossil-bearing marlstone (M). Samples 123-765C-39R-3, 61-64 cm, -35R-2, 113-117 cm, and -36R-2, 24-26 cm. 4. Calcispheres, quartz, opaque grains, phosphate, and mica concentrated in B division lamina; Sample 123-765C-36R-2, 24-26 cm. 

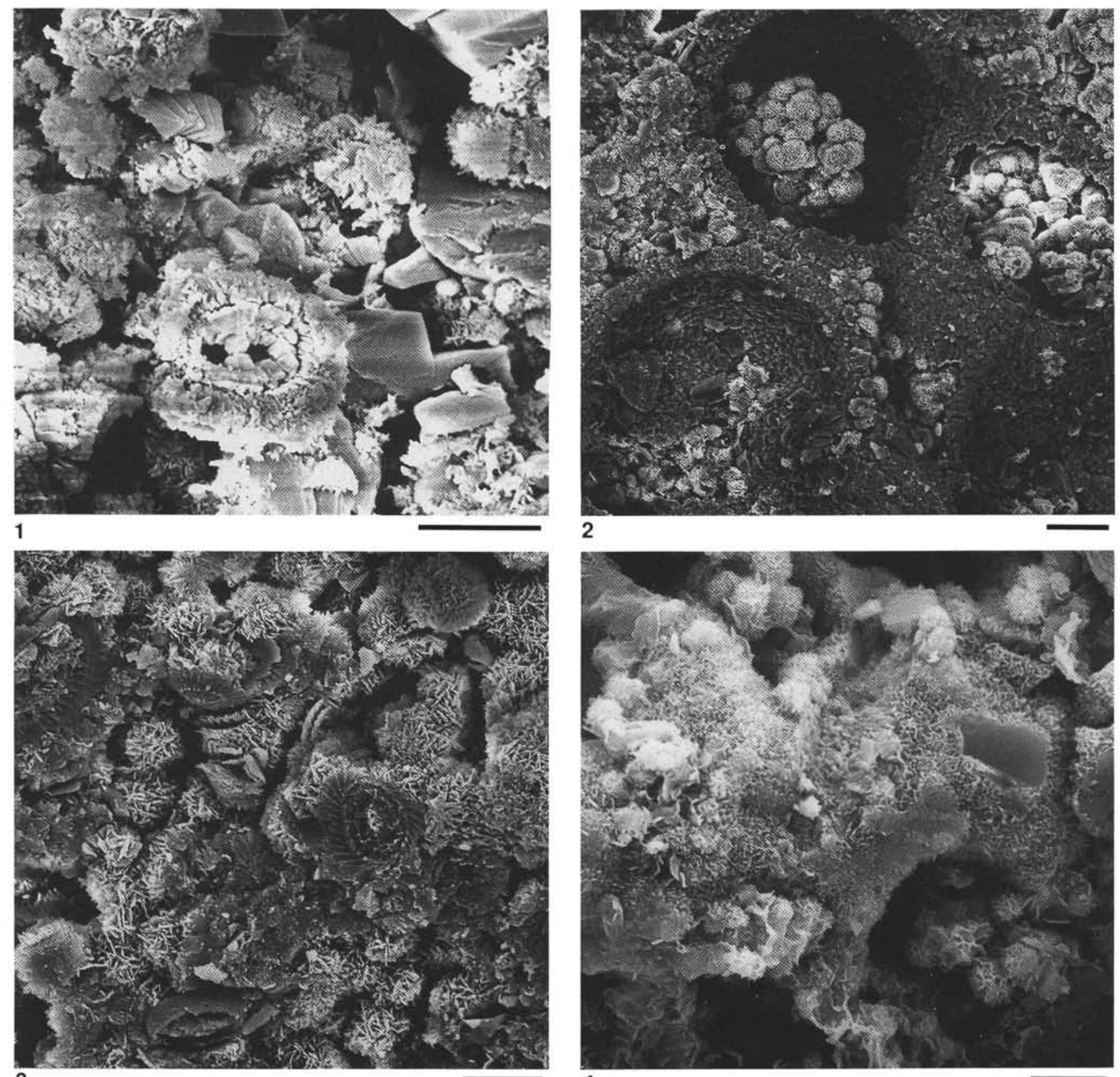

2

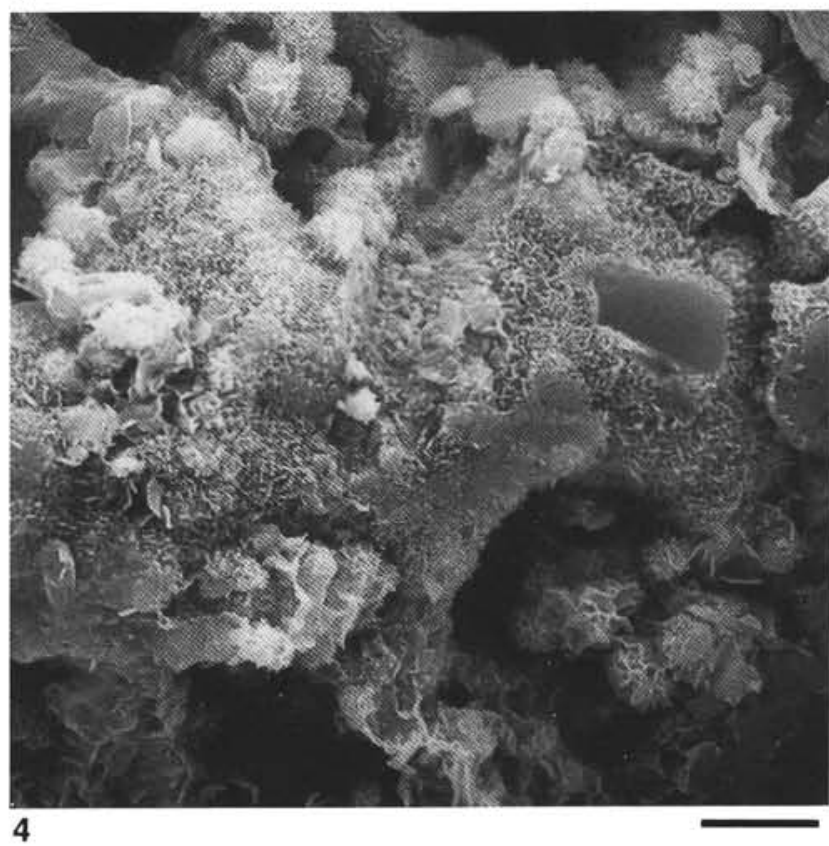

Plate 5. SEM micrographs of Aptian coarse-grained turbidites; scale bars equal $5 \mu \mathrm{m}$ for $\mathbf{1}, \mathbf{3}$, and $\mathbf{4}$, and $10 \mu \mathrm{m}$ for $\mathbf{2}$. 1. Recrystallized nannofossil and rhombs of rhodochrosite; Sample 123-765C-40R-4,54-57 cm. 2. Foraminifer test partially filled with opal-CT lepispheres; sample 123-765C-34R-4, 66-68 cm. 3. Close-up of B showing nannofossils (Watznaueria sp.) and opal-CT lepispheres; coccolith shields etched and partly replaced by silica. 4. Radiolarian test replaced by opal-CT lepispheres; Sample 35-2, 97-99 cm. 